\title{
Biurowość w czasach pandemii. Wpływ epidemii COVID-19 na informatyzację biurowości w jednostkach administracji samorządowej ${ }^{1}$
}

\author{
Katarzyna Pepłowska
}

Uniwersytet Mikołaja Kopernika w Toruniu / Nicolaus Copernicus University in Toruń (Poland) kpeplowska@umk.pl, ORCID 0001-5364-684X

\section{STRESZCZENIE}

Artykuł zawiera podsumowanie efektów badań przeprowadzonych w ramach realizacji grantu pt. „Biurowość w czasach pandemii. Wpływ epidemii COVID-19 na informatyzację biurowości w administracji publicznej". Celem projektu była analiza i ocena dotychczasowych działań w zakresie informatyzacji biurowości w Polsce oraz udzielenie odpowiedzi na pytania o wpływ epidemii COVID-19 na pracę jednostek administracji samorządowej, wprowadzanie nowych, niespotykanych dotąd rozwiązań, technologii i otwierających się możliwości w bezpośrednim następstwie stanu nadzwyczajnego, a także pytań o ich jakość, trwałe konsekwencje, sposoby załatwiania spraw urzędowych i wykonywania czynności kancelaryjnych oraz zainteresowanie obywateli elektronicznym świadczeniem usług przez urzędy administracji publicznej.

\section{SŁOWA KLUCZOWE}

pandemia,

COVID-19, informatyzacja

biurowości, e-usługi, administracja samorządowa, informatyzacja, biurowość, system EZD, SARS-CoV-2

\section{Office environments in times of pandemic. The impact of the COVID-19 outbreak on digitization of office work in local government units}

\section{ABSTRACT}

The SARS-CoV-2 coronavirus pandemic has caused unprecedented global crises in the areas of health, politics, society, and economics and has affected all aspects of human life. We are witnessing unprecedented events that undoubtedly have long-term consequences and will affect the image of the modern world for years to come. The new reality requires unprecedented
KEYWORDS

pandemic, COVID-19, office digitization, e-services, local government,

1 Artykuł zawiera wyniki badań przeprowadzonych jako część realizacji grantu „Biurowość w czasach pandemii. Wpływ epidemii COVID-19 na informatyzację biurowości w administracji publicznej”. Grant uzyskany w ramach konkursu „CRUSH - badania nad pandemią COVID-19 realizowane na UMK przez przedstawicieli Nauk Społecznych i Humanistycznych" został sfinansowany w ramach programu Inicjatywa Doskonałości - Uczelnia Badawcza. Projekt realizowany w latach 2020-2021 przez badaczy z UMK: Katarzynę Pepłowską i Marcina Smoczyńskiego. Wszystkie kwestionariusze przygotowane w związku z badaniem oraz odpowiedzi przesłane przez respondentów udostępniono jako raw data na stronie internetowej projektu: https:// dobrepraktyki.umk.pl/. Pozostałe dane badawcze zgromadzone w toku realizacji projektu przechowywane są w siedzibie Wydziału Nauk Historycznych Uniwersytetu Mikołaja Kopernika w Toruniu, ul. Wł. Bojarskiego 1, 87-100 Torun. 
crisis solutions, but it is also worthwhile to pay attention to those practices that can positively influence the surrounding reality. One of such areas may be pandemic-related office practices and accelerated digitization of the activities of public administration. The impact of COVID-19 pandemic on the work of local government units, introduction of new, unprecedented solutions, technologies and possibilities, allow us to pose questions about their quality, lasting consequences, ways of handling administrative matters and performing clerical activities, as well as interest of citizens in electronic provision of services by public administration offices. This article - as part of the deliverables of research conducted under a grant entitled „Office practices in times of pandemic. The impact of the COVID-19 epidemic on digitization of office work in public administration" - aims to summarize actions taken so far in the field of computerization of office work in Poland and to provide answers to the above questions in context of operation of local governments where clerical activities were carried out by means of the traditional system. computerization, office, EDM system, SARS-CoV-2

\section{Słowo wstępne}

W okresie od 14 do 20 marca 2020 r. w granicach Rzeczypospolitej obowiązywał stan zagrożenia epidemicznego, natomiast dnia 20 marca, rozporządzeniem Ministra Zdrowia, ogłoszono stan epidemii². Równocześnie - by przeciwdziałać rozprzestrzenianiu się wirusa - wprowadzono obostrzenia w zakresie życia społecznego, gospodarki, edukacji, kultury oraz funkcjonowania podmiotów publicznych.

W związku z pandemią jednostki chorobowej COVID-19 niemal wszystkie urzędy administracji publicznej diametralnie zmieniły wewnętrzny system swojej pracy i tryb kontaktów z otoczeniem zewnętrznym ${ }^{3}$. Gros z jednostek organizacyjnych niemal zupełnie zamknęło swoje stacjonarne oddziały, wdrożyło hybrydowy (stacjonarny i zdalny) sposób pracy, przeniosło funkcjonowanie do świata wirtualnego z wykorzystaniem systemów teleinformatycznych. Bez żadnych wątpliwości można stwierdzić, że nowa, wywołana pandemią rzeczywistość, tj. nagła, zewnętrzna i bardzo silna potrzeba przeniesienia działalności do świata wirtualnego, stała się asumptem spontanicznej informatyzacji róż-

2 Rozporządzenie Ministra Zdrowia z dnia 13 marca 2020 r. w sprawie ogłoszenia na obszarze Rzeczypospolitej Polskiej stanu zagrożenia epidemicznego (Dz. U. 2020, poz. 433); Rozporządzenie Ministra Zdrowia z dnia 20 marca 2020 r. w sprawie ogłoszenia na obszarze Rzeczypospolitej Polskiej stanu epidemii (Dz. U. 2020, poz. 491).

3 K. Kubicka-Żach, Praca zdalna w administracji przedłużona do 17 stycznia, https://www.prawo.pl/samorzad/praca-zdalna-w-administracji-zostala-przedluzona,504789.html [dostęp: 17.03.2021]. 
nych aspektów funkcjonowania podmiotów publicznych w Polsce, w tym także biurowości ${ }^{4}$.

Wpływ epidemii COVID-19 na pracę jednostek administracji samorządowej, wprowadzanie w bezpośrednim następstwie kryzysowej sytuacji niespotykanych dotąd rozwiązań, technologii i możliwości, pozwalają postawić pytania o ich jakość, trwałe konsekwencje, sposoby załatwiania spraw urzędowych i wykonywania czynności kancelaryjnych.

Niniejszy artykuł - jako część efektów badań przeprowadzonych w ramach realizacji grantu pt. „Biurowość w czasach pandemii. Wpływ epidemii COVID-19 na informatyzację biurowości w administracji publicznej" - stawia sobie za cel określenie wpływu pandemii Covid-19 na informatyzację biurowości ${ }^{5}$ w kontekście funkcjonowania jednostek administracji samorządowej, w których czynności kancelaryjne wykonywano w systemie tradycyjnym ${ }^{6}$.

\section{O badaniu}

Badanie „Biurowość w czasach pandemii. Wpływ epidemii COVID-19 na informatyzację biurowości w administracji publicznej” zostało podzielone na dwie merytoryczne części. Pierwszą, której wyniki prezentowane są na łamach niniejszego tekstu, i drugą, odnoszącą się do jednostek pracujących w oparciu o system $\mathrm{EZD}^{7}$.

4 Biurowości rozumianej jako grupa formalnych czynności (sensu stricto aktotwórczych) niezbędnych do kierowania przepływem i utrwaleniem informacji w formie dokumentacji oraz jej gromadzenia i przetwarzania, zob.: H. Robótka, Wspótczesna biurowość. Zagadnienia ogólne, Biblioteka Zarządcy Dokumentacji, t. 1, Toruń 2010, s. 24. Przenosząc naukową definicję na praktyczny grunt, można ją rozpatrywać jako zasady postępowania z dokumentacją, dokumentowanie i sposób dokumentowania czynności prawnych oraz innych czynności urzędowych. Należy zdawać sobie sprawę, że działania określane mianem „biurowości” są esencją działalności każdej jednostki organizacyjnej, szczególnie proweniencji publicznej.

5 Pełna ocena rzeczywistego wpływu pandemii na informatyzację biurowości jednostek samorządowych będzie możliwa za kilka lat. Autorzy badania planują poddać badaniu realny wpływ dzisiejszych doświadczeń na rozwój biurowości.

6 Wg przepisów wynikających z załącznika nr 1 do Rozporządzenia Prezesa Rady Ministrów z dnia 18 stycznia 2011 r. w sprawie instrukcji kancelaryjnej, jednolitych rzeczowych wykazów akt oraz instrukcji w sprawie organizacji i zakresu działania archiwów zakładowych (Dz. U. 2011, nr 14, poz. 67) - dalej: rozporządzenie PRM z 2011 r.

7 Zob. niniejszy tom: M. Smoczyński, Biurowość w czasach pandemii. Wpływ epidemii Covid-19 na informatyzację biurowości w jednostkach administracji samorządowych i rzadowych w terenie. 
Diagnoza wpływu epidemii koronawirusa SARS-CoV-2 na informatyzację biurowości w jednostkach samorządowych przebiegała w kilku etapach. Pierwszym z nich było wytypowanie urzędów objętych badaniem - jednostek administracji samorządowej funkcjonujących w ramach prawnych Rozporządzenia Prezesa Rady Ministrów z dnia 18 stycznia 2011 r. w sprawie instrukcji kancelaryjnej, jednolitych rzeczowych wykazów akt oraz instrukcji w sprawie organizacji i zakresu działania archiwów zakładowych ${ }^{8}$. Obranie takiego kryterium pozwoliło na analizę funkcjonowania podmiotów pracujących według tożsamych normatywów kancelaryjnych. Na podstawie informacji publicznej odnoszącej się do sposobów wykonywania czynności kancelaryjnych w jednej z trzech form (w systemie tradycyjnym ${ }^{9}$ bez wspomagania narzędziami teleinformatycznymi, w systemie tradycyjnym wspomaganym narzędziami teleinformatycznymi lub w systemie EZD) wydzielono trzy grupy badawcze. Do grupy pierwszej zaliczono 39 jednostek pracujących w trybie tradycyjnym, które zdeklarowały brak wspomagania systemami teleinformatycznymi w pracy (w tym 28 urzędów gminy, 6 urzędów miejskich, 2 urzędy miasta i gminy, 3 starostwa powiatowe) w 15 województwach ${ }^{10}$. W grupie drugiej znalazły się 43 jednostki organizacyjne z 16 województw, które - według deklaracji - działały w systemie tradycyjnym, ale wykonywanie czynności kancelaryjnych i wewnętrzny obieg pism wspomagały narzędziem informatycznym (EZD PUW lub innym ${ }^{11}$ ). Na tę grupę badawczą złożyło się 20 urzędów gminy, 10 urzędów miasta, 4 urzędy miasta i gminy oraz 9 starostw powiato-

8 Rozporządzenie PRM z 2011 r.

9 Zgodnie z §2 pkt 14 rozporządzenia PRM z 2011 r., system tradycyjny jest definiowany jako system wykonywania czynności kancelaryjnych, dokumentowania przebiegu załatwiania spraw, gromadzenia i tworzenia dokumentacji w postaci nieelektronicznej, z możliwością korzystania z narzędzi informatycznych do wspomagania procesu obiegu dokumentacji w tej postaci.

10 Żadna z wytypowanych do kontaktu jednostek organizacyjnych z województwa opolskiego nie zadeklarowała funkcjonowania kancelarii w systemie tradycyjnym bez wspomagającego narzędzia teleinformatycznego.

11 Jednostki objęte badaniem najczęściej wskazywały na następujące systemy wspomagające wykonywanie czynności kancelaryjnych: System E-obieg, Aplikacja e-Dokumenty firmy Record SI Sp. z o.o., elektroniczny obieg dokumentów - eDOK, system eKancelaria, IntraDok firmy Wasko S.A., EZD - MDOK, EDICTA, „SIDAS” firmy „Madkom”, „Elektroniczne Zarządzanie Dokumentacją" firmy Comarch, Elektroniczny system obiegu dokumentów, DOKUS, System Elektronicznego Obiegu Dokumentów „PROTON”, SmartDoc, system obiegu dokumentów „SOD”. Dane uzyskano na podstawie dokumentacji zebranej w toku projektu. 
wych $^{12}$. Oddzielną grupę badawczą (trzecią) stanowiły jednostki funkcjonujące w systemie EZD ${ }^{13}$.

Wybór jednostek objętych badaniem przebiegał w sposób celowy i wynikał z założenia, wedle którego w bardziej rozbudowanych jednostkach mogło zaistnieć większe prawdopodobieństwo szerszego wykorzystania systemów do e-biurowości. Ważnym kryterium branym pod uwagę był podział kraju na województwa, powiaty oraz gminy miejskie i wiejskie. Przyjęto założenie, że badaniem będzie objęta reprezentatywna grupa jednostek większych i mniejszych, działających na różnych szczeblach podziału terytorialnego i w różnych geograficznie regionach.

Drugim etapem było zaproszenie do wzięcia udziału w badaniach kierowników i pracowników wytypowanych jednostek oraz ankietyzacja. Dla dwóch grup badawczych przygotowano łącznie cztery ankiety z wykorzystaniem Systemu Badań Ankietowych Uniwersytetu Mikołaja Kopernika w Toruniu ${ }^{14}$. Narzędzie - oparte na wolnym oprogramowaniu LimeSurvey - pozwoliło na opracowanie i rozesłanie kwestionariuszy, a następnie zgromadzenie i analizę odpowiedzi udzielonych przez respondentów ${ }^{15}$.

Dla pracowników jednostek grupy 1. (biurowość w systemie tradycyjnym bez wspomagania narzędziami teleinformatycznymi) utworzono dwie ankiety. Pierwszą, składającą się z szesnastu obowiązkowych pytań zamkniętych oraz jednego otwartego, skierowano do szczebla kierowniczego ${ }^{16}$. Drugą, zawierającą trzynaście pytań obowiązkowych jedno- i wielokrotnego wyboru i dwa otwarte, adresowano do pozostałych zatrudnionych ${ }^{17}$. Pytania dotyczyły m.in.: efektywności działań jednostek w sytuacji kryzysowej, podstaw prawnych nowej organizacji pracy, konieczności przeprowadzania dodatkowych szkoleń, dobrych praktyk wdrożonych w obliczu pandemii koronawirusa, zainteresowania obywateli e-usługami, potrzeby wprowadzenia w jednostce systemu klasy EZD oraz odczuć

12 Założeniem projektu była pełna anonimowość uczestników badania.

13 Wyniki badań obejmujących tę grupę zostały opublikowane oddzielnie, zob.: M. Smoczyński, op.cit.

14 System Badań Ankietowych, https://www.uci.umk.pl/index.php/System_Badań_Ankietowych [dostęp: 18.03.2020]. Szczegółowe informacje dotyczące wykorzystanego w badaniu narzędzia dostępne są na stronie internetowej: LimeSurvey, https://www.limesurvey.org [dostęp: 18.03.2021].

15 Szczegółowe informacje dotyczące wykorzystanego w badaniu narzędzia dostępne są na stronie internetowej: LimeSurvey, https://www.limesurvey.org [dostęp: 18.03.2021].

16 W tej grupie uzyskano łącznie 30 odpowiedzi.

17 W tej ankiecie wypowiedziało się łącznie 128 respondentów. 
urzędników w związku z nową sytuacją. Podobnie przygotowano kwestionariusze przesłane do pracowników szczebla kierowniczego oraz niższych szczebli zatrudnionych w jednostkach organizacyjnych, w których pracę kancelarii wspomagano narzędziem informatycznym (podmioty grupy 2). Kierownikom jednostek (a także komórek organizacyjnych) zadano łącznie osiemnaście pytań (siedemnaście obowiązkowych z wyborem odpowiedzi oraz jedno nieobowiązkowe z możliwością dowolnej wypowiedzi) ${ }^{18}$. Pozostałym pracownikom zadano $\mathrm{w}$ sumie szesnaście pytań (w tym czternaście obowiązkowych zamkniętych oraz dwa nieobowiązkowe otwarte $)^{19}$. Pytania skierowane do obu grup dotyczyły m.in.: wydajności pracy, kwestii przygotowania urzędu oraz personelu do pracy z nowymi narzędziami, wdrożenia systemu EZD i dobrych praktyk z zakresu informatyzacji biurowości wprowadzonych do użytku w czasie pandemii. Ankiety były aktywne w okresie od 12 listopada 2020 r. do 1 marca 2021 r.

Symultanicznie do każdej z wytypowanych jednostek organizacyjnych rozesłano wnioski o udostępnienie informacji publicznej, co stanowiło odrębny etap diagnozy. W zapytaniach poproszono o udzielenie kilkunastu danych, w tym m.in.: odnoszących się do rocznej i miesięcznej liczby wpływów w formie elektronicznej w 2019 r. oraz w 2020 r., liczby potwierdzonych profili zaufanych $\mathrm{w}$ tych samych latach, inwestycji w sprzęt informatyczny poczynionych od marca 2020 r., ogłoszenia wewnętrznych normatywów regulujących pracę w czasie pandemii, sposobów archiwizowania poczty elektronicznej i rejestrowania wpływów przychodzących na skrzynki mailowe pracowników, ewentualnych planów dot. wdrożenia systemu EZD.

Dzięki wykorzystanym narzędziom i przyjętej metodologii badań zgromadzono obszerny materiał do analizy, obejmujący łącznie 426 wypowiedzi urzędników oraz 813 odpowiedzi udzielonych w trybie dostępu do informacji publicznej ${ }^{20}$. Intencją koordynatorów projektu było zapewnienie pełnej anonimowości wszystkim uczestnikom badania i prezentowanie wyników w ujęciu kompleksowym, a nie indywidualnym. $Z$ tego względu, opisując rezultaty poszukiwań, nie powo-

18 W sumie uzyskano 69 odpowiedzi.

19 Ankietę wypełniło łącznie 199 respondentów.

20 Wszystkie kwestionariusze przygotowane w związku z badaniem, raporty oraz odpowiedzi przesłane przez respondentów udostępniono jako raw data na stronie internetowej projektu, zob.: Biurowość w czasie pandemii. Wpływ epidemii COVID-19 na informatyzację biurowości w administracji publicznej, https://dobrepraktyki.umk.pl/ [dostęp: 18.03.2021]. Koordynatorzy badania zastrzegają sobie możliwość opracowywania i rozpowszechniania danych zebranych w ramach projektu badawczego. 
łuję się na konkretne pisma uzyskane drogą dostępu do informacji publicznej, a całość dokumentacji zebranej w toku projektu. Wszelkie zgromadzone w toku projektu materiały źródłowe przechowywane są w siedzibie Wydziału Nauk Historycznych Uniwersytetu Mikołaja Kopernika w Toruniu przy ul. Wł. Bojarskiego 1. Wszyscy zainteresowani mogą się z nimi swobodnie zapoznać (jednakże po zanonimizowaniu danych) po uprzednim kontakcie z koordynatorami badania.

\section{Funkcjonowanie urzędów w czasie pandemii}

W związku z pandemią COVID-19 w Polsce wprowadzono szereg ograniczeń, nakazów i zakazów w celu spowolnienia rozprzestrzeniania epidemii. Obostrzenia dotyczyły również działalności i organizacji pracy urzędów administracji publicznej, w tym jednostek samorządowych.

Przeciwdziałanie COVID-19 zostało zdefiniowane w przepisach prawa jako „suma wszelkich czynności związanych ze zwalczaniem zakażenia, zapobieganiem rozprzestrzenianiu się, profilaktyką oraz zwalczaniem skutków, w tym społeczno-gospodarczych tej choroby" ${ }^{21}$. W związku z powyższym dotychczasowe praktyki związane z działalnością i funkcjonowaniem jednostek publicznych musiały zostać dostosowane do sytuacji kryzysowej.

Wraz z wejściem w życie przepisów rozporządzenia Ministra Zdrowia z dnia 13 marca 2020 r. w sprawie ogłoszenia na obszarze Rzeczypospolitej Polskiej stanu zagrożenia epidemicznego ograniczono działalność urzędów administracji publicznej. Zdecydowano o wykonywaniu wyłącznie zadań niezbędnych do zapewnienia pomocy obywatelom, wyłączając jednocześnie bezpośrednią obsługę interesantów. Zgodnie z $§ 8$ rozporządzenia decyzje dotyczące rodzaju i formy wprowadzonych ograniczeń podejmowali kierownicy jednostek ${ }^{22}$. Przepisy w tym zakresie były wielokrotnie zmieniane pod wpływem rozwoju sytuacji epidemicznej. Normatywne ograniczenie funkcjonowania i organizacji działalności urzędów nastąpiło z dniem ogłoszenia stanu zagrożenia epidemicznego na mocy Rozporządzenia Rady Ministrów z dnia 10 kwietnia 2020 r. w sprawie ustanowie-

21 Ustawa z dnia 2 marca 2020 r. o szczególnych rozwiązaniach związanych z zapobieganiem, przeciwdziałaniem i zwalczaniem COVID-19, innych chorób zakaźnych oraz wywołanych nimi sytuacji kryzysowych (Dz. U. 2020, poz. 1842) - dalej: Specustawa koronawirusowa.

22 Rozporządzenie Ministra Zdrowia z dnia 13 marca 2020 r. w sprawie ogłoszenia na obszarze Rzeczypospolitej Polskiej stanu zagrożenia epidemicznego (Dz. U. 2020, poz. 433). 
nia określonych ograniczeń, nakazów i zakazów w związku z wystąpieniem stanu epidemii ${ }^{23}$.

W zdecydowanej większości jednostek objętych badaniem ograniczenia i zmiany systemu pracy wprowadzono na podstawie przepisów wewnętrznych wydanych przez kierowników. Regulacje te leżały w granicach prawa powszechnie obowiązującego, rekomendacji organów administracji rządowej oraz zaleceń Głównego Inspektora Sanitarnego. Analizie poddano 35 normatywów wewnętrznych obowiązujących w badanych jednostkach. Złożyły się na nie regulaminy wewnętrzne oraz zarządzenia wydawane przez kierowników jednostek. Wskazały one na organizację pracy w ścisłym reżimie sanitarnym wraz z rozwiązaniami zmierzającymi do ochrony klientów i pracowników jednostek.

Urzędy pracowały w systemie hybrydowym. Wprowadzono rotacyjny system pracy, dzieląc zatrudnionych na tryb zmianowy, a tam gdzie było to możliwe, organizowano pracę zdalną, czyli wykonywaną poza siedzibą urzędu ${ }^{24}$. Przeniesienie wykonywania pracy poza siedzibę urzędu było obostrzone następującymi przesłankami: charakter pracy musiał pozwalać na zmianę miejsca jej wykonywania, a zatrudniony posiadać umiejętności konieczne do pracy w zmienionym trybie i możliwości techniczne oraz odpowiednie warunki lokalowe. Co warto podkreślić, odpowiedzialność za zapewnienie sprzętu oraz materiałów leżała po stronie pracodawców. Pracownicy mogli korzystać z prywatnych urządzeń jedynie wtedy, gdy zapewniały ochronę wszelkich informacji oraz danych osobowych. Zdecydowana większość badanych jednostek zadeklarowała, że organizacja pracy zdalnej była normowana przepisami wewnętrznymi wydanymi przez kierownika jednostki (wykres 1).

Poddane analizie normatywy wewnętrzne obowiązujące w badanych jednostkach wykazały zróżnicowaną głębię informacyjną i różnorodny zakres merytoryczny regulacji. Niektóre normatywy szczegółowo omawiały pracę zdalną, inne natomiast traktowały problem lakonicznie. Pracownicy na ogół zostali zobowiązani do zabezpieczenia sprzętu i posiadanych danych (również tych znajdujących się na nośnikach papierowych) przed osobami postronnymi, w tym wspólnie z nimi zamieszkującymi, oraz przestrzegania polityk bezpieczeństwa. Powyższa przesłanka pozwala twierdzić, że powszechnie zezwalano na pobieranie doku-

23 Rozporządzenie Rady Ministrów z dnia 10 kwietnia 2020 r. w sprawie ustanowienia określonych ograniczeń, nakazów i zakazów w związku z wystąpieniem stanu epidemii (Dz. U. 2020, poz. 658). W okresie od 10 kwietnia 2020 r. do 21 marca 2021 r. było ono 14 razy nowelizowane.

24 Polecenie wykonywania pracy zdalnej wynikało $\mathrm{z}$ art. 3 specustawy koronawirusowej. 
mentacji poza siedziby urzędów, a niektóre normatywy traktowały tę kwestię jednoznacznie i expressis verbis precyzowały pobieranie dokumentacji z urzędów oraz zasady korzystania z tej możliwości.

Wykres 1. Organizacja pracy zdalnej w okresie epidemii koronawirusa SARS-CoV-2

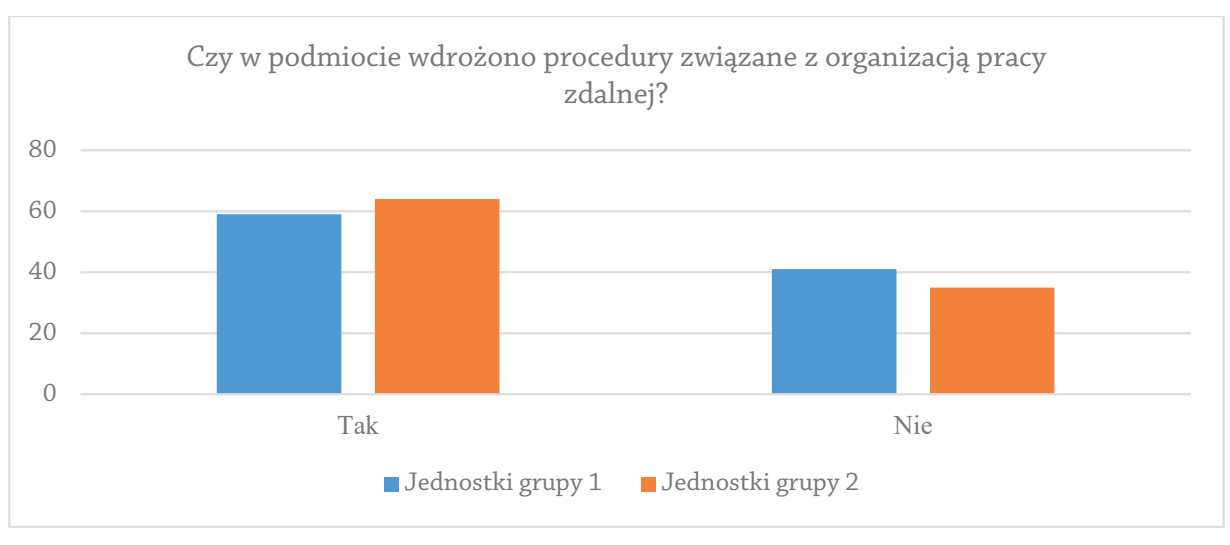

Opracowanie własne na podstawie dokumentacji zebranej w toku projektu.

Niektóre z zarządzeń oraz regulaminów pracy zdalnej szczegółowo określały zadania pracowników związane z obowiązkiem zapewnienia bezpieczeństwa, w tym również cyberbezpieczeństwa. Instruowały o środkach ostrożności koniecznych do zachowania przy komunikacji elektronicznej, m.in. w formie regulaminu bezpieczeństwa stanowiącego załącznik do przedmiotowego zarządzenia. Określano m.in.: zasady przekazywania danych, zasady pracy z dokumentacją aktową wyniesioną poza siedzibę urzędu, kwestię bezpiecznego łącza internetowego oraz procedurę postępowania w przypadku zaistnienia incydentu bądź naruszenia związanego z przetwarzaniem danych osobowych ${ }^{25}$.

\section{Wpływ epidemii na sposób załatwiania spraw}

Jednym z najważniejszych celów badania było ustalenie wpływu pandemii koronawirusa SARS-CoV-2 na sposób załatwiania spraw urzędowych. Ten - ze względu na utrzymującą się przed długi czas trudną sytuację epidemiczną - mu-

25 Ochrona danych osobowych podczas pracy zdalnej, https://uodo.gov.pl/pl/file/2786 [dostęp: 26.03.2021]. 
siał zostać poddany modyfikacjom umożliwiającym zachowanie reżimów sanitarnych, ograniczenie kontaktów bezpośrednich, pracę w trybie hybrydowym lub zupełnie zdalnym. Konieczne więc okazało się załatwianie spraw z wykorzystaniem narzędzi elektronicznych oraz komunikacji na odległość, a spontaniczna informatyzacja usług oferowanych przez urzędy stała się faktem, z którym zgodziła się większość respondentów badania (wykres 2$)^{26}$.

Wykres 2. Pandemia koronawirusa SARS-CoV-2 a spontaniczna informatyzacja usług oferowanych przez urzędy

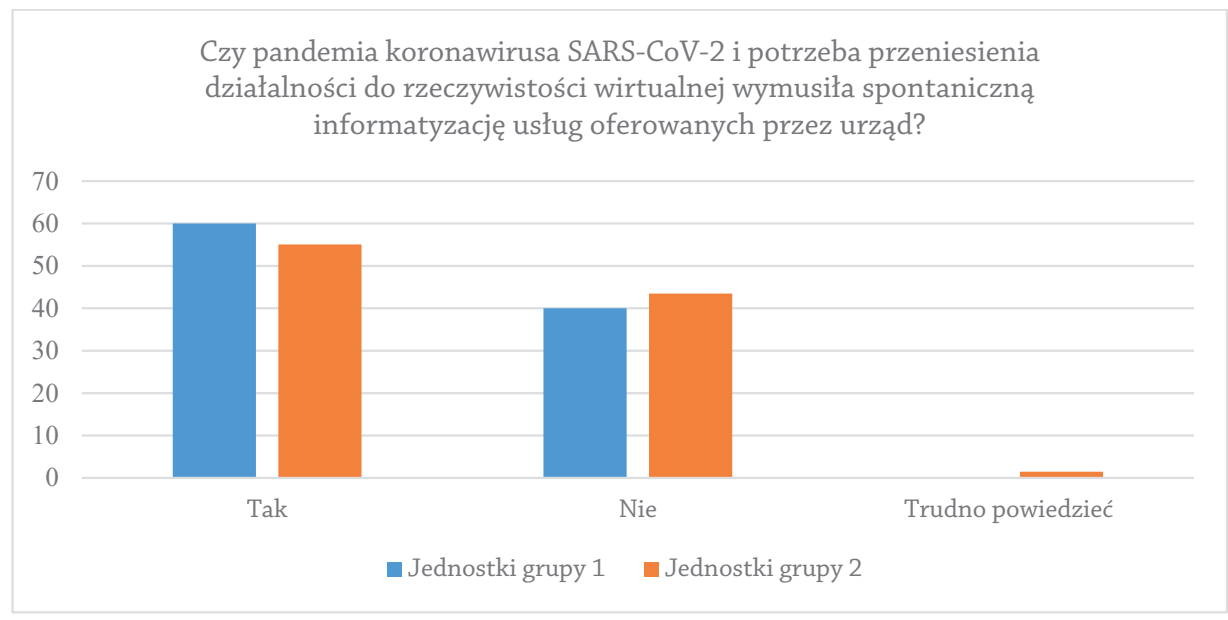

Opracowanie własne na podstawie dokumentacji zebranej w toku projektu.

Przyspieszenie działań w zakresie informatyzacji biurowości zostało w większym stopniu dostrzeżone w jednostkach, które w badaniu przypisano do grupy 1 , czyli niewspomagających się system teleinformatycznym w codziennej pracy. Można zatem wnioskować, że skutki epidemii koronawirusa w kontekście

26 Epidemia zapoczątkowana w 2020 r. wpłynęła także na zainteresowanie korzystaniem z Profilu zaufanego (dalej: PZ), w dużej mierze w zakresie rejestracji na szczepienia. PZ umożliwia jednak załatwianie różnych spraw urzędowych on-line, a zatem sytuacja pandemiczna może w konsekwencji wpływać na większą świadomość obywateli w zakresie usług publicznych świadczonych drogą elektroniczną. Na początku kwietnia 2021 r. do PZ logowało się 500 osób na sekundę, a obłożenie systemu wzrosło 100-krotnie, zob.: Rzq̨d zapowiada zaszczepienie wszystkich 60-latków do końca miesiąca, https://www.onet.pl/informacje/onetwiadomosci/rzad-zapowiada-zaszczepienie-wszystkich-60-latkow-do-konca-miesiaca/17s2psx,79cfc278 [dostęp: 2.04.2021]. 
biurowości w większym stopniu wpłynęły na te podmioty, w których informatyzacja usług publicznych postępowała do tej pory z mniejszą intensywnością.

Jednoznacznie należy stwierdzić, że zdaniem ankietowanych okres pandemii upowszechnił wykorzystanie dokumentu elektronicznego w komunikacji urzędowej oraz ułatwił dostęp do usług publicznych i załatwiania spraw za pomoc narzędzi cyfrowych (wykresy 3-4) ${ }^{27}$.

Wykres 3. Pandemia koronawirusa SARS-CoV-2 a upowszechnienie i ułatwienie dostępu do usług publicznych i załatwiania spraw za pomocą narzędzi cyfrowych

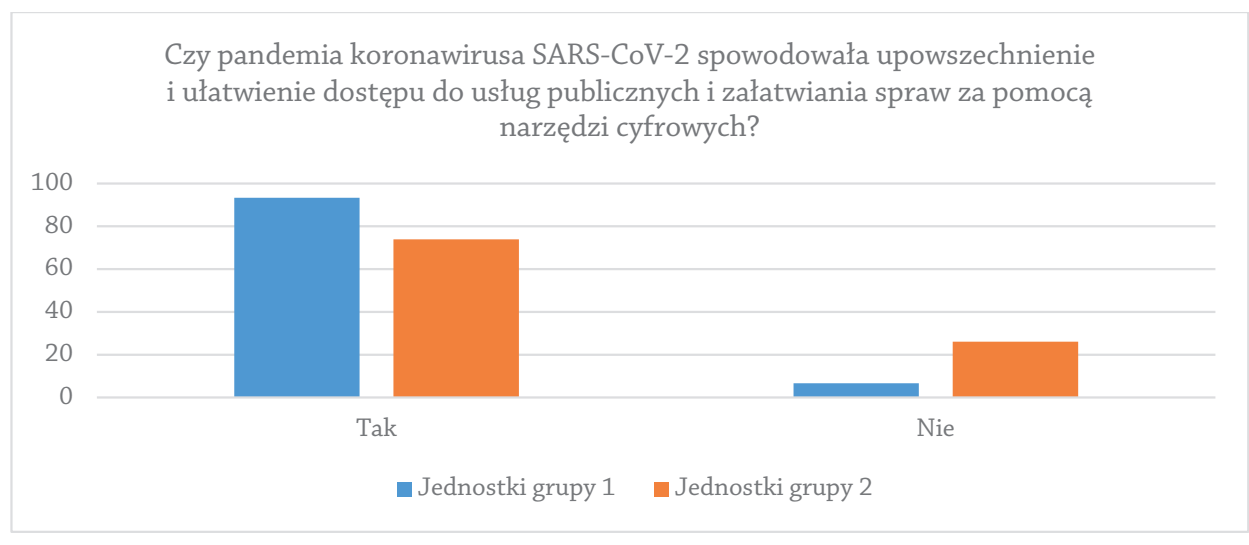

Opracowanie własne na podstawie dokumentacji zebranej w toku projektu.

Informacje te potwierdzają dane uzyskane od jednostek wytypowanych do badania w drodze dostępu do informacji publicznej (zob. wykresy 5-6). W 2020 r. sprawy urzędowe z wykorzystaniem platformy ePUAP załatwiano znacząco częściej niż w roku poprzednim, a największy wzrost w tym zakresie można zaobserwować od marca 2020 r., czyli od momentu wprowadzenia najpierw stanu zagrożenia epidemicznego, a potem stanu epidemii. Wzrost zainteresowania możliwościami platformy pokrywa się z dwoma okresami wzmożonych obostrzeń sanitarnych i czasem wzrastania liczby zarażeń - od marca do lipca, a następnie jesienią, tj. od października do grudnia ${ }^{28}$. Ogółem w jednostkach grupy 1 przez

27 Szerokie wykorzystanie formy dokumentu elektronicznego zostało również wyartykułowane w specustawie koronawirusowej. Ustawodawca aż dwadzieścia razy odwołał się do dokumentu elektronicznego jako formy załatwienia spraw, złożenia oświadczenia woli oraz jego mocy dowodowej; zob.: Specustawa koronawirusowa.

28 Adekwatnie do wydawanych kolejno Rozporządzeń Rady Ministrów w sprawie ustanowienia określonych ograniczeń, nakazów i zakazów w związku z wystąpieniem stanu epidemii. 
ePUAP wpłynęło średnio o ponad 26\% pism więcej, natomiast w jednostkach grupy 2 nastąpił niemal dwukrotny wzrost ${ }^{29}$. Powyższe dane w pełni korespondują $\mathrm{z}$ ujęciem ogólnopolskim ${ }^{30}$.

Wykres 4. Upowszechnienie wykorzystania dokumentu elektronicznego w komunikacji urzędowej

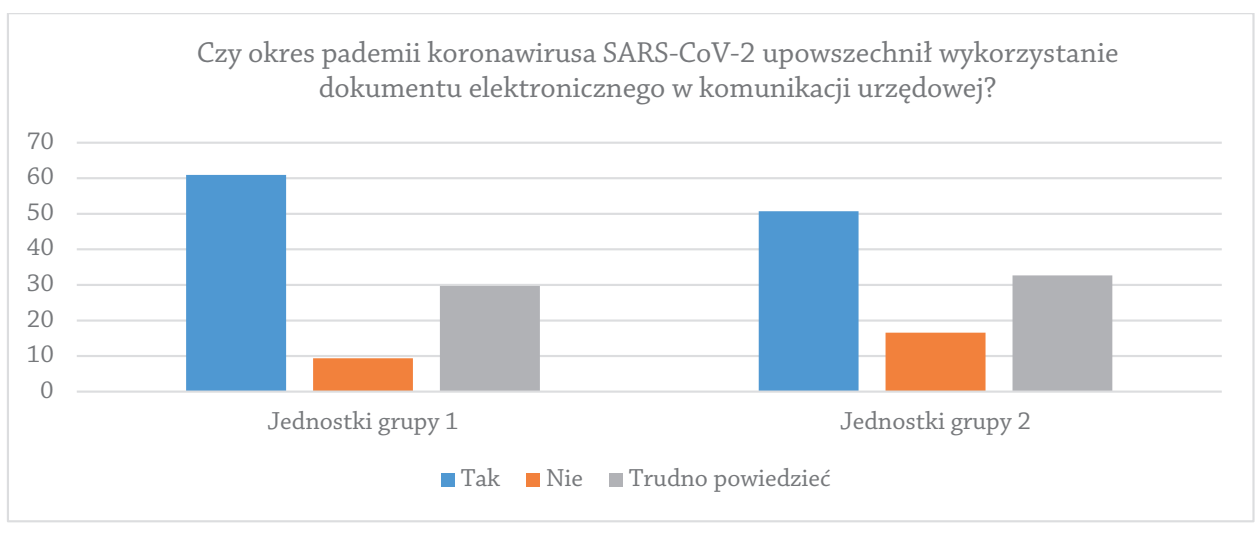

Opracowanie własne na podstawie dokumentacji zebranej w toku projektu.

Respondenci badania w odniesieniu do praktyk i rozwiązań związanych z biurowością, które zostały wdrożone w urzędach lub wykorzystywane na szerszą niż wcześniej skalę w związku z epidemią, na pierwszym miejscu wskazali wykorzystanie poczty elektronicznej oraz telefoniczne i internetowe umawianie wizyt w urzędach. Do mniej powszechnych praktyk należało załatwianie spraw poprzez platformę ePUAP oraz scentralizowane przygotowywanie kopii cyfrowych wpływających pism i późniejsze ich przesyłanie w takiej postaci pracownikom jednostki. Rzadko zdarzały się wdrożenia systemów wspomagających biurowość oraz wirtualne wizyty w urzędach (wykres 7).

29 Na podstawie dokumentacji zebranej w toku projektu.

30 W całym 2020 r. przez platformę ePUAP wpłynęło do urzędów o 38\% więcej ogólnych pism niż w roku poprzednim (ze stałą tendencją zwyżkową), zob. Widok.gov.pl. Statystyki usług: ePUAP - Pismo ogólne do podmiotu publicznego - stary wzór, https://widok.gov.pl/services/ePUAP-Pismo-ogolne-do-podmiotu-publicznego-stary-wzor/ [dostęp: 31.03.2021]. 
Wykres 5. Liczba pism wpływających przez platformę ePUAP w latach 2019-2020 w jednostkach grupy 1

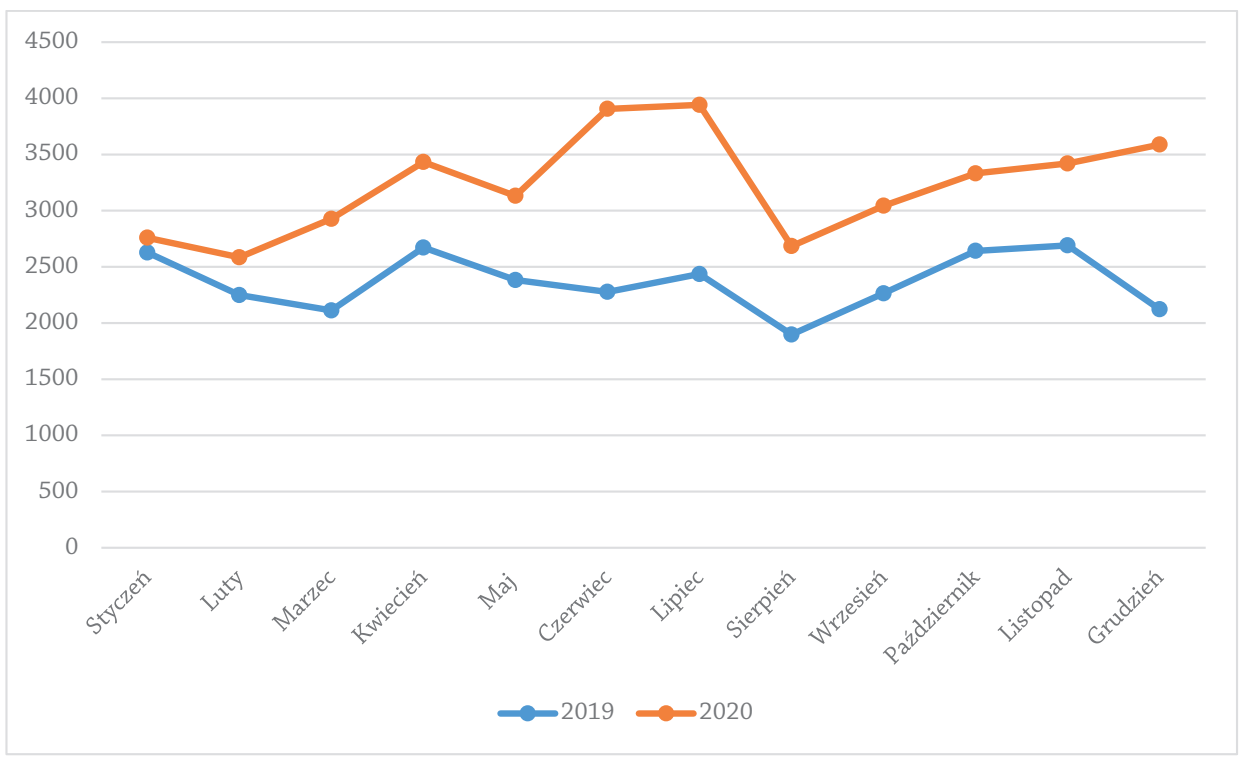

Opracowanie własne na podstawie dokumentacji zebranej w toku projektu.

Wykres 6. Liczba pism wpływających przez platformę ePUAP w latach 2019-2020 w jednostkach grupy 2

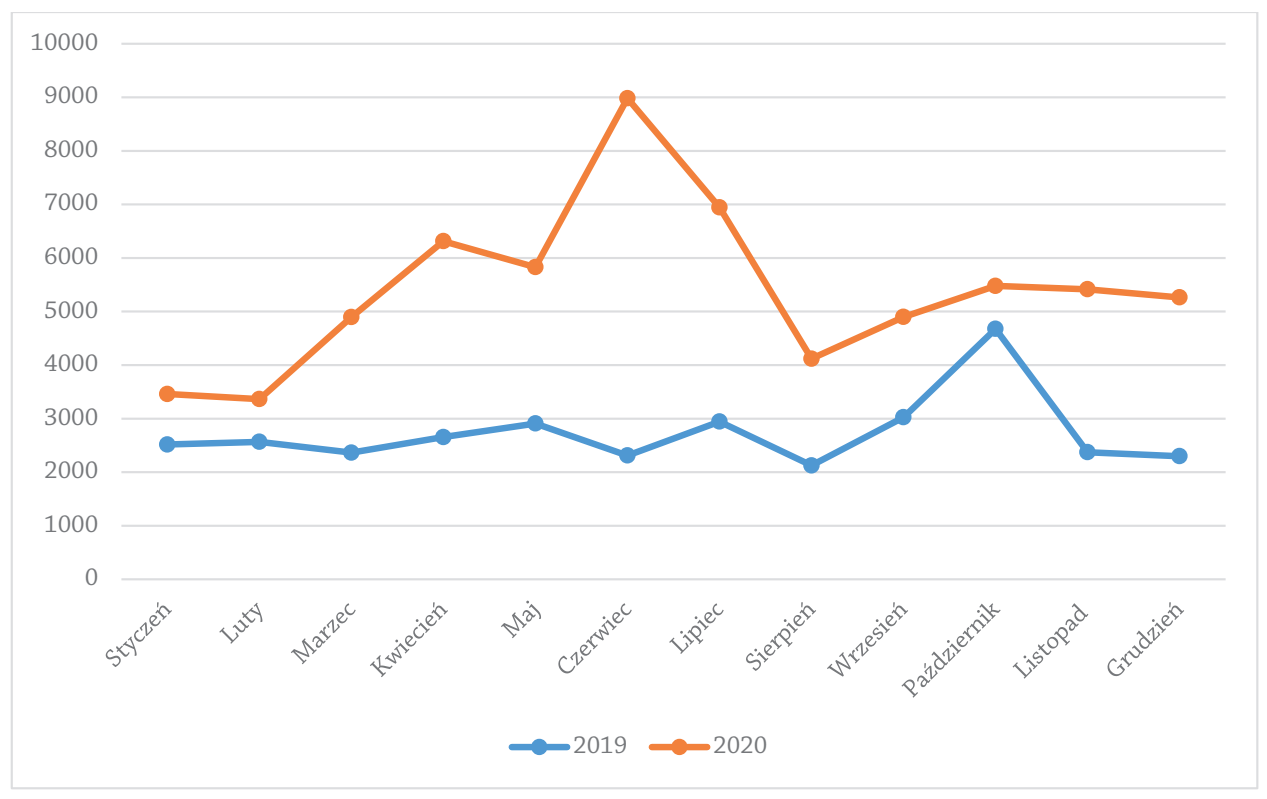

Opracowanie własne na podstawie dokumentacji zebranej w toku projektu. 
Wykres 7. Praktyki i rozwiązania związane z biurowością wdrożone w urzędzie w związku z epidemią

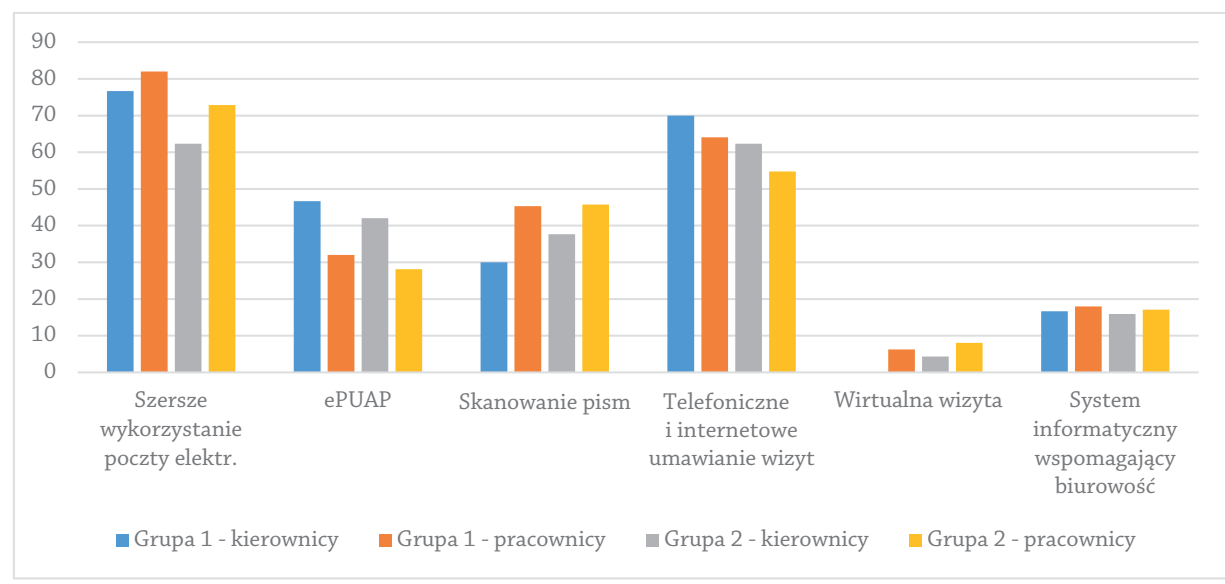

Opracowanie własne na podstawie dokumentacji zebranej w toku projektu.

Do narzędzi służących elektronicznemu załatwianiu spraw, które najczęściej wykorzystywano, należą: korespondencja elektroniczna, e-mail połączony z rozmową telefoniczną oraz kontakt telefoniczny (wykres 8 ) $^{31}$. Zdecydowanie rzadziej ankietowani wskazali na ePUAP. Niewielkie wykorzystanie ePUAP dowodzi wciąż marginalnego wykorzystania utworzonej w 2005 r. platformy teleinformatycznej, która z założenia miała stanowić podstawowy kanał komunikacji elektronicznej obywateli z jednostkami administracji publicznej ${ }^{32}$. Tymczasem aż 68,47\% respondentów wskazało, że z platformy ePUAP nie korzystało w ogóle lub czyniło to w bardzo ograniczonym stopniu ${ }^{33}$. Taki stan może pośrednio wynikać m.in. z komunikatów udostępnianych przez urzędy, które zachęcały do kontaktów za pomocą poczty elektronicznej oraz telefonicznie, natomiast platfor-

31 Na podstawie dokumentacji zebranej w toku projektu.

32 Platforma ePUAP miała usprawnić i upowszechnić elektroniczną drogę dostępu do usług administracji publicznej, ale także - co warto podkreślić - od 2006 r. miała być jednym z kluczowych narzędzi służących realizacji celów priorytetowych w procesie informatyzacji administracji, zob.: Rozporządzenie Rady Ministrów z dnia 28 marca 2007 r. w sprawie Planu Informatyzacji Państwa na lata 2007-2010 (Dz. U. 2007, nr 61, poz. 415). Więcej na temat relacji platformy ePUAP z informatyzowaniem biurowości zob.: H. Robótka, Zarzq̨dzanie dokumentacją w dobie informatyzacji [w:] Zarzq̨dzanie dokumentacją w instytucji. Czynniki sprzyjające i ograniczenia, Biblioteka Zarządcy dokumentacji, t. 9, red. R. Degen, M. Jabłońska, Toruń 2020, s. 97-116.

33 Niektórzy z respondentów zgłaszali, że w ogóle nie mieli dostępu do platformy ePUAP, co utrudniało proces załatwienia spraw i powodowało konieczność ich przekazania innym urzędnikom. 
ma ePUAP nie była formą przez nie preferowaną ${ }^{34}$. Ponadto niewiele, około 5\%, z jednostek objętych badaniem pełniło funkcję podmiotu potwierdzającego profil zaufany, co niewątpliwie było barierą dla osób wykluczonych komunikacyjnie ${ }^{35}$.

Wykres 8. Częstotliwość korzystania z narzędzi do elektronicznego załatwiania spraw

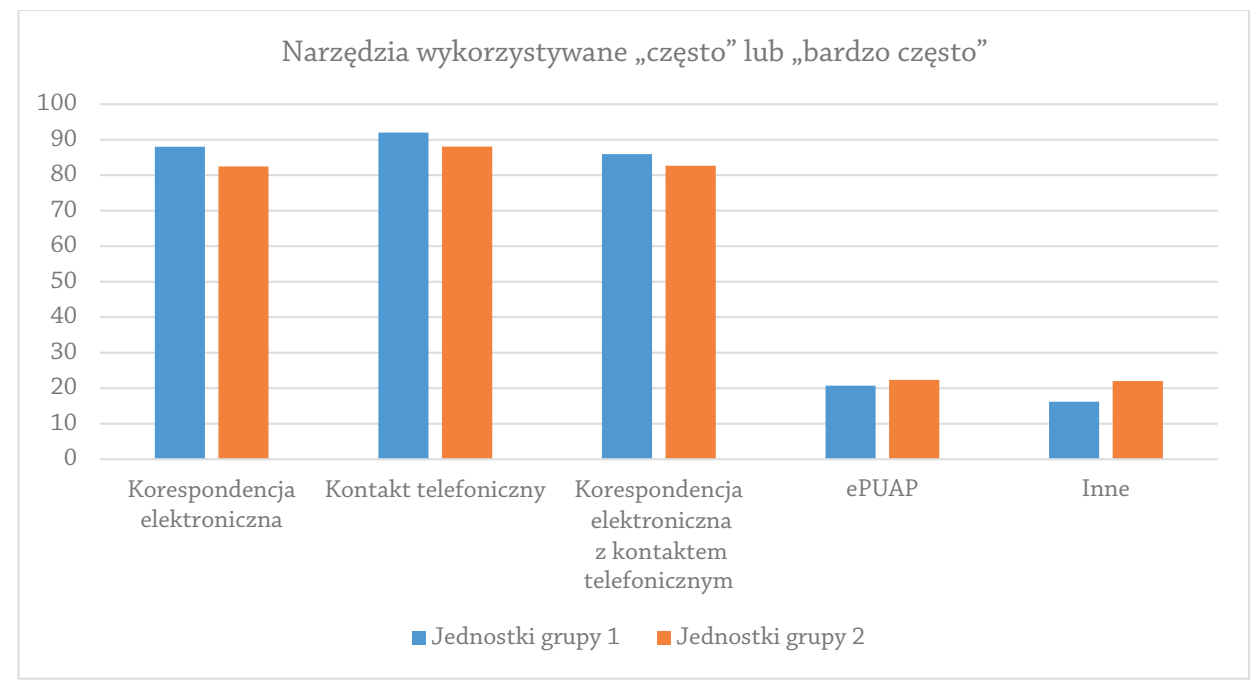

Opracowanie własne na podstawie dokumentacji zebranej w toku projektu.

Mimo że korespondencja elektroniczna we wszystkich przebadanych jednostkach stanowiła najczęściej wykorzystywane i podstawowe narzędzie komunikacji w sytuacji kryzysowej, jedynie niewielka część urzędów wdrożyła zasady postępowania z e-mailami, w tym związane z ich archiwizacją. Pełne, odrębne regulacje znalazły zastosowanie w 16\% urzędów objętych badaniem, częściowe natomiast - w niespełna $3 \%{ }^{36}$. Dane te nie korespondują z wynikami badania ankietowego, skierowanego do szczebla kierowniczego, gdzie łącznie aż 70\% respondentów wskazało, że takie procedury opracowano przed lub po wybuchu epidemii. Kwestia unormowania zasad postępowania $z$ dokumentacją elektroniczną, w tym także napływającą na indywidualne skrzynki pocztowe, została dostrzeżona przez

34 Wniosek wynikający z obserwacji informacji zamieszczonych na stronach internetowych jednostek objętych badaniem.

35 Na podstawie dokumentacji zebranej w toku projektu.

36 Załącznik nr 1 do rozporządzenia PRM z 2011 r. w ograniczonym tylko stopniu podejmuje zagadnienie postępowania z dokumentacją napływającą poprzez pocztę elektroniczną na Elektroniczną Skrzynkę Podawczą oraz na informatycznym nośniku danych. 
pracowników niższych szczebli. Aż 82\% ankietowanych stwierdziło, że w obliczu doświadczeń związanych z pandemią należy przygotować i wdrożyć zasady postępowania z dokumentacją elektroniczną w zakresie załatwiania spraw oraz archiwizacji (wykres 9).

Wykres 9. Potrzeba opracowania zasad postępowania z dokumentacją elektroniczną

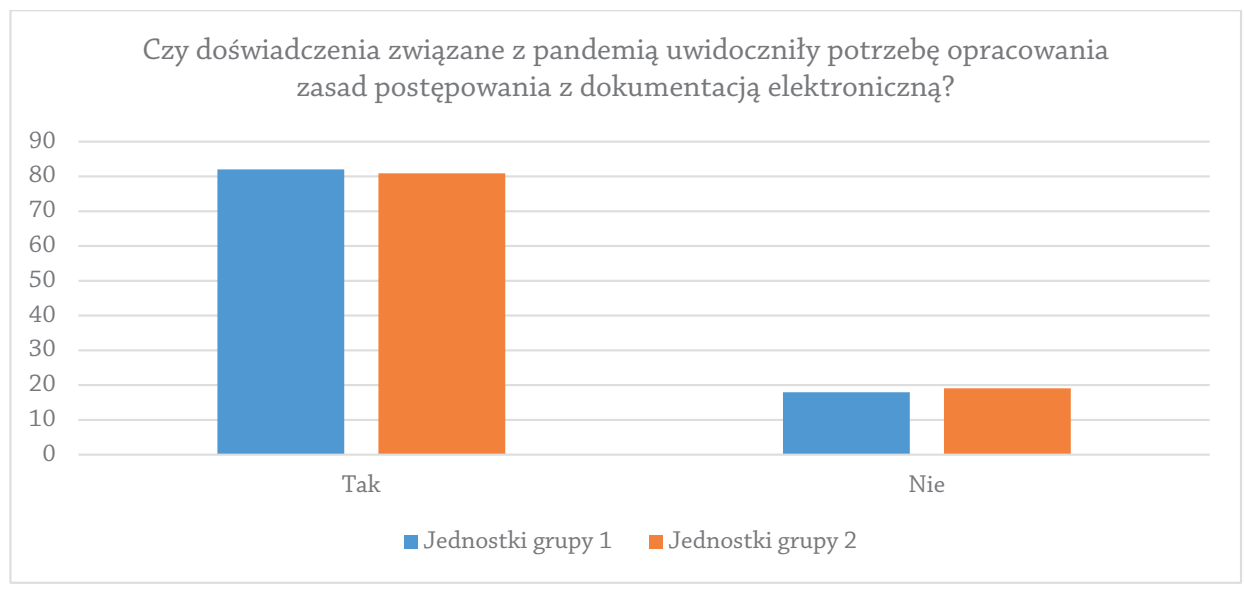

Opracowanie własne na podstawie dokumentacji zebranej w toku projektu.

Kolejnym ujawnionym w toku badań problemem były zróżnicowane praktyki w zakresie rejestracji korespondencji wpływającej na adresy skrzynek elektronicznych pracowników. W niemal 30\% jednostek rejestrowane były wszystkie przesyłki, w pozostałych urzędach natomiast jedynie cześć korespondencji, spełniającej określone kryteria ${ }^{37}$.

Ważną zasadą odnoszącą się do zarządzania dokumentacją jest osiąganie efektywności w postępowaniu z informacją utrwaloną na jakimkolwiek nośniku podczas jej całego cyklu życia. Efektywność w tym przypadku można rozumieć w różnorodny sposób. Według prof. Roberta Degena jest to takie zorganizowanie wytwarzania dokumentacji w instytucji, by konieczność „produkcji aktowej” nie odwracała uwagi pracowników od realizacji statutowych celów i wypełniana zadań merytorycznych ${ }^{38}$. Efektywność można rozpatrywać także w kategoriach

37 Na podstawie dokumentacji zebranej w toku projektu.

38 R. Degen, Zarządzenie dokumentacją w polskich badaniach, [w:] Zarzadzanie dokumentacją. Badanie i praktyka, Biblioteka Zarządcy Dokumentacji, t. 7, red. idem, M. Jabłońska, Torun 2016 , s. 51-52; M. Smoczyński, Współczesny zarządca dokumentacji a zarzq̨dzający aktami specjalista-organizator wg koncepcji Jana Kościołka, „Archiwa - Kancelarie - Zbiory” 2017, nr 8 (10), s. 119. 
nauki o ekonomii i zarządzaniu. Wówczas oznacza osiąganie wyników przy możliwie najniższych nakładach pracy i środków finansowych. Wg teorii zarządzania to produktywne wykorzystanie posiadanych zasobów dla realizacji przyjętych celów $^{39}$. Nie ma żadnych przeciwskazań, by rozpatrywać efektywność w najprostszy, słownikowy sposób, czyli jako działania „dające dobre wyniki, wydajne” 40 . Jak więc sytuacja pandemiczna wpłynęła na wydajność pracy uczestników badania? W większości stwierdzono, że rozwiązania zastosowane w sytuacji kryzysowej pozwoliły na utrzymanie efektywności równej do tej osiąganej przed wybuchem epidemii. W obu grupach zarysowało się jednak spore, bo osiągające ponad $40 \%$ ogółu, grono pracowników, których wydajność uległa obniżeniu (wykres 10). Ostatecznie wpływ zmian w zakresie funkcjonowania i organizacji pracy urzędów w okresie pandemii oceniono w większości jako neutralny (wykres 11).

Wykres 10. Wydajność pracy w okresie pandemii - pracownicy

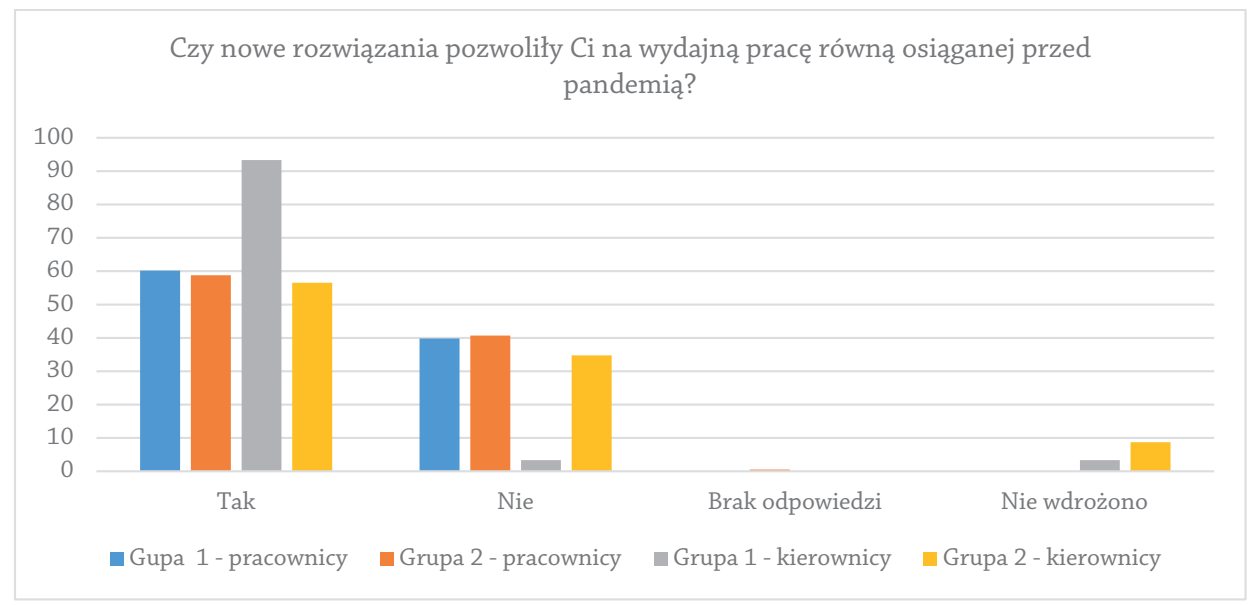

Opracowanie własne na podstawie dokumentacji zebranej w toku projektu.

Przyczynami obniżonej wydajności pracy w porównaniu do tej, którą obserwowano przed wybuchem epidemii były z pewnością trudności i problemy, wynikające ze zmiany sposobu wykonywania obowiązków urzędowych. W obu grupach za największą barierę uznano brak wiedzy i świadomości klientów w zakresie możliwości i sposobów korzystania z nowoczesnych form komuni-

39 E. Szymańska, Efektywność przedsiębiorstw - definiowanie i pomiar, „Roczniki Nauk Rolniczych” 2010, t. 97, s. 156.

40 Efektywny, [hasło w:] Słownik języka polskiego PWN, http://sjp.pwn.pl/szukaj/efektywno\%C5\%9B\%C4\%87.html [dostęp: 29.03.2021]. 
kacji z urzędem. Często pojawiały się także problemy natury technicznej - brak stabilnego łącza internetowego oraz niedostateczny dostęp do odpowiedniego sprzętu. Trzecią najczęstszą, w ocenie respondentów, barierą był brak wdrożonego w podmiocie systemu do elektronicznego zarządzania dokumentacją, który w sposób automatyczny wykonywałby wiele czynności kancelaryjnych. Do rzadziej pojawiających się czynników ograniczających należały: brak podpisu elektronicznego, brak jasno określonych procedur postępowania z dokumentacją elektroniczną, brak doświadczenia w zakresie wykorzystywania elektronicznych narzędzi oraz obawy własne urzędników w związku z wykorzystywaniem nowych technologii (wykres 12). Wskazane trudności wyraźniej dostrzeżono w jednostkach grupy 2 .

Wykres 11. Wypływ zmian w zakresie funkcjonowania i organizacji pracy urzędu w okresie epidemii

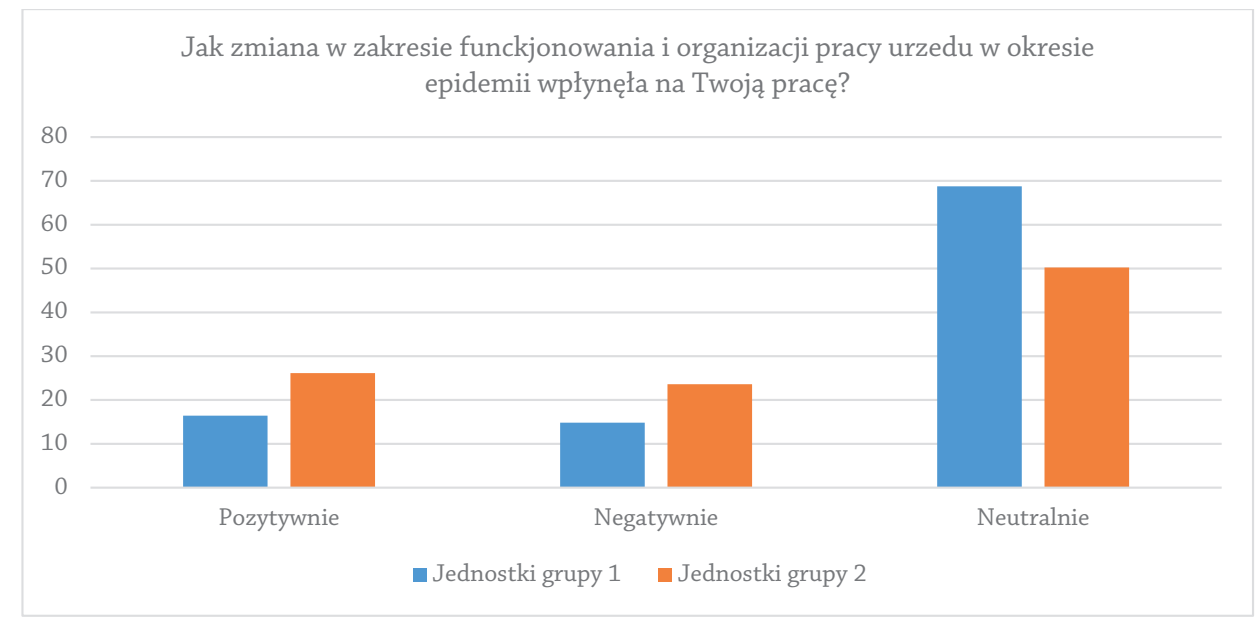

Opracowanie własne na podstawie dokumentacji zebranej w toku projektu.

Pomimo trudności pojawiających się w toku wykonywania obowiązków służbowych $\mathrm{w}$ warunkach pandemii, generalna ocena zmian wdrożonych w sytuacji kryzysowej jest pozytywna. Przeważająca większość ankietowanych oceniła jako skuteczne praktyki związane z wykorzystaniem dokumentu elektronicznego i komunikacji na odległość stosowane przez podmioty w okresie pandemii. Co warto podkreślić, w opinii respondentów rozwiązania te mogłyby mieć zastosowanie na stałe, po ustaniu zagrożenia epidemicznego (wykres 13). 
Wykres 12. Trudności napotykane w toku wykonywania pracy w okresie tzw. lockdownu

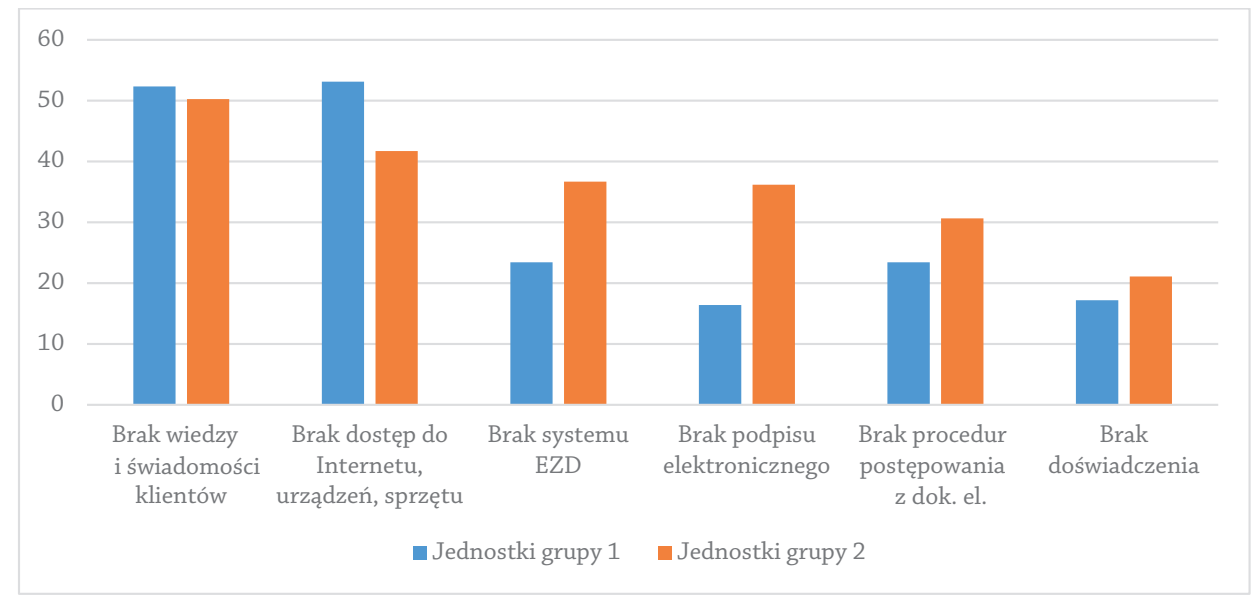

Opracowanie własne na podstawie dokumentacji zebranej w toku projektu.

Wykres 13. Ocena skuteczności wykorzystania dokumentu elektronicznego i komunikacji elektronicznej

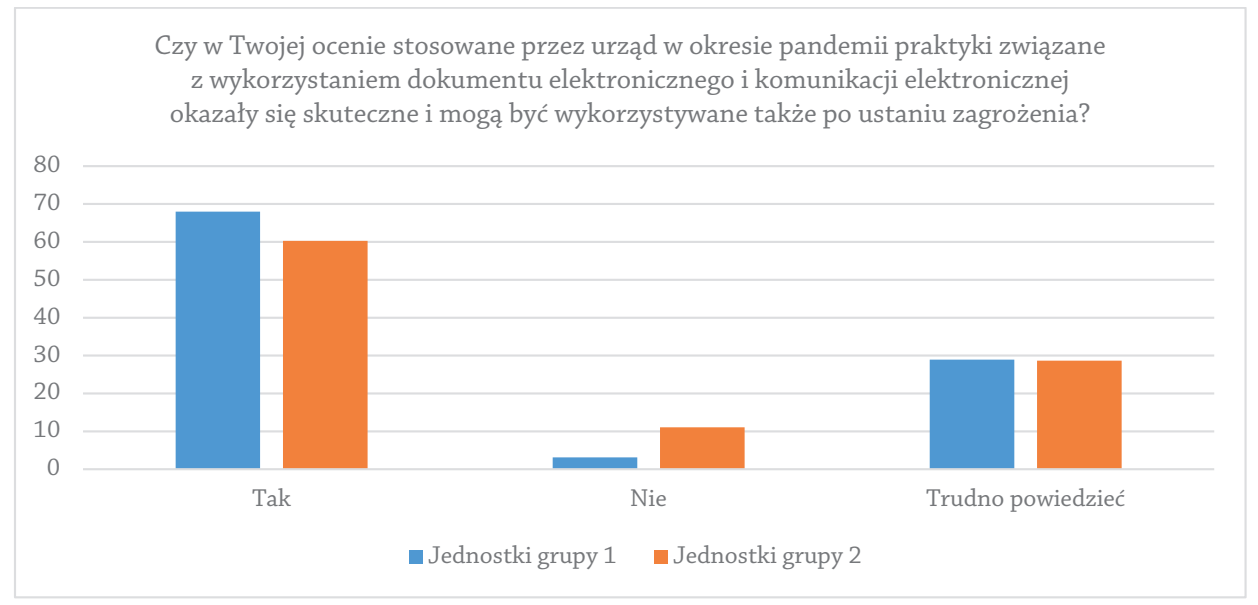

Opracowanie własne na podstawie dokumentacji zebranej w toku projektu.

Jak podkreślono powyżej, jedną z głównych trudności w pracy wykonywanej w warunkach obostrzeń pandemicznych był brak wdrożonego systemu EZD. Wniosek ten - co zasługuje na szczególne podkreślenie - łączy się z powszechnym, przeważającym przeświadczeniem respondentów, że doświadczenia z okresu epidemii COVID-19 uwidoczniły potrzebę pełnego wprowadzenia systemu elektronicznego zarządzania dokumentacją do działalności urzędów. Z tym 
stwierdzeniem zgodziło się 63,06\% uczestników badania (zob. wykres 14), przy czym częściej byli to pracownicy szeregowi, rzadziej natomiast kadra kierownicza jednostek, która podejmuje decyzje dotyczące zmian organizacyjnych i rozwoju informatyzacji. Ogółem aż 62,50\% (pracownicy jednostek grupy 1.) oraz 68,34\% (pracownicy jednostek grupy 2.) stwierdziło, że wdrożenie systemu do elektronicznego zarządzania dokumentacją mogłoby korzystnie wpłynąć na funkcjonowanie urzędu oraz na dokumentowanie przebiegu załatwiania spraw i archiwizację dokumentacji ${ }^{41}$.

Wykres 14. Potrzeba pełnego wdrożenia systemu EZD w działalności urzędu

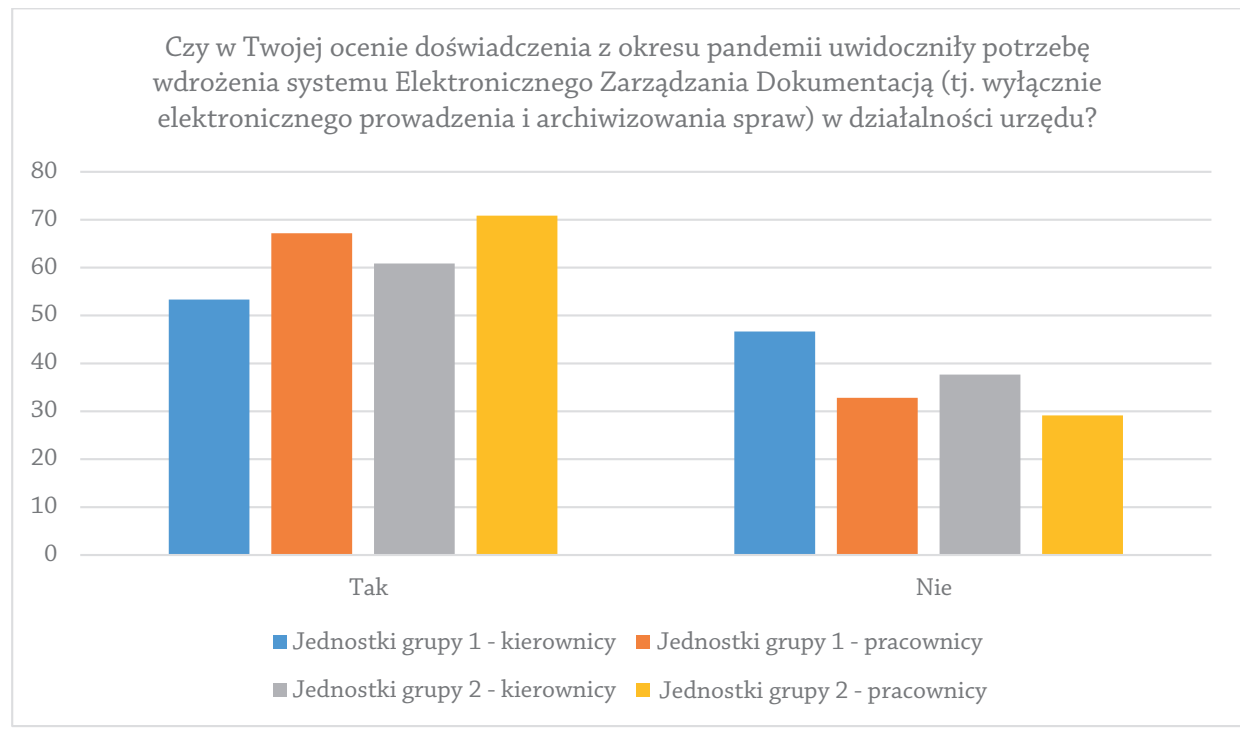

Opracowanie własne na podstawie dokumentacji zebranej w toku projektu.

W przeciwieństwie do pozytywnych ocen dotyczących planów wdrożenia systemu EZD była kwestia gotowości urzędu do definitywnego odejścia od systemu tradycyjnego. Jedynie około 33\% pracowników zgodziło się w pełni ze stwierdzeniem, że urząd po doświadczeniach związanych z działalnością w okresie pandemii jest gotowy do wdrożenia sytemu elektronicznego zarządzania dokumentacją. Brak takiej gotowości zadeklarowało niemal $13 \%$ ankietowanych. Zarysowało się ponadto szerokie, bo ponad $50 \%$ grono osób niezdecydowanych ${ }^{42}$.

41 Na podstawie dokumentacji zebranej w toku projektu.

42 Ibidem. 


\section{Wyposażenie techniczne}

Kwestia wyposażenia technicznego, nader ważna dla sprawnego funkcjonowania jakiejkolwiek jednostki organizacyjnej w normalnych warunkach, nabrała znacznie większego znaczenia w obliczu sytuacji kryzysowej. Zmieniona organizacja pracy, w tym także powszechne stosowanie trybu pracy zdalnej, świadczonej najczęściej w warunkach domowych, wymagała odpowiedniego wyposażenia technicznego, m.in. odpowiedniego sprzętu komputerowego, oprogramowania (np. edytorów tekstu), stabilnego i bezpiecznego łącza internetowego, urządzeń umożliwiających uzyskanie dostępu do danych przechowywanych cyfrowo oraz - bardzo często - software'u pozwalającego na korzystanie z tzw. pulpitu zdalnego ${ }^{43}$. Osobno należy wskazać urządzenia niezbędne do zachowania ciągłości w świadczeniu usług publicznych, a wykorzystywane na miejscu, tj. w stacjonarnych siedzibach urzędów. Były to m.in. skanery do wykonywania kopii cyfrowych pism wpływających w formie tradycyjnej.

Konieczność zapewnienia odpowiedniego wyposażenia umożliwiającego pracę zdalną tylko częściowo została zrealizowana przez zgodę na korzystanie z urządzeń prywatnych. Było to związane z wymaganiami, dotyczącymi bezpieczeństwa danych ${ }^{44}$. Nie wszyscy pracownicy administracji samorządowej dysponowali własnym sprzętem, niezbędnym do efektywnego wykonywania pracy zdalnej (zob. wykres 13). Od urzędów wymagało to, aby w ślad za zmianami organizacyjnymi podjęte zostały inwestycje. Od marca 2020 r. do stycznia 2021 r. blisko $87 \%$ podmiotów objętych badaniem zakupiło sprzęt informatyczny niezbędny do pracy biurowej. Łączna kwota zakupów zrealizowanych w tych jednostkach opiewała na kwotę 2667 184,89 zł. Zakupy obejmowały szeroką gamę urządzeń, w szczególności: komputery i zestawy komputerowe, urządzenia wielofunkcyjne, skanery, monitory, tablety, drukarki etykiet, czytniki kodów kreskowych oraz kamery internetowe. Zakupiono także oprogramowanie, w szczególności systemy operacyjne, aplikacje do pracy zdalnej oraz programy antywirusowe ${ }^{45}$.

Zrealizowane $\mathrm{w}$ okresie pandemii inwestycje przeczą odpowiedziom udzielonym przez respondentów szczebla kierowniczego w badaniu ankie-

43 Pulpit zdalny to rozwiązanie służące uzyskaniu dostępu do innego komputera. Pozwala na otrzymanie wglądu w zasoby innego systemu operacyjnego oraz umożliwia zdalne korzystanie z oprogramowania zainstalowanego na innym komputerze.

45 Na podstawie dokumentacji zebranej w toku projektu. 
towym (wykres 15). W zdecydowanej większości uznali oni, że urzędy były techniczne przygotowane do elektronicznego załatwiania spraw jeszcze przed wybuchem epidemii. Odmiennego zdania było jedynie $6,67 \%$ (jednostki grupy 1) oraz 10,14\% (jednostki grupy 2) ankietowanych. Można zatem wnioskować, że zakupów dokonywano w związku z koniecznością wykonywania pracy zdalnej, a nie szerszym wykorzystaniem dokumentu elektronicznego w biurowości.

Wykres 15. Techniczne przygotowanie do elektronicznego załatwiania spraw

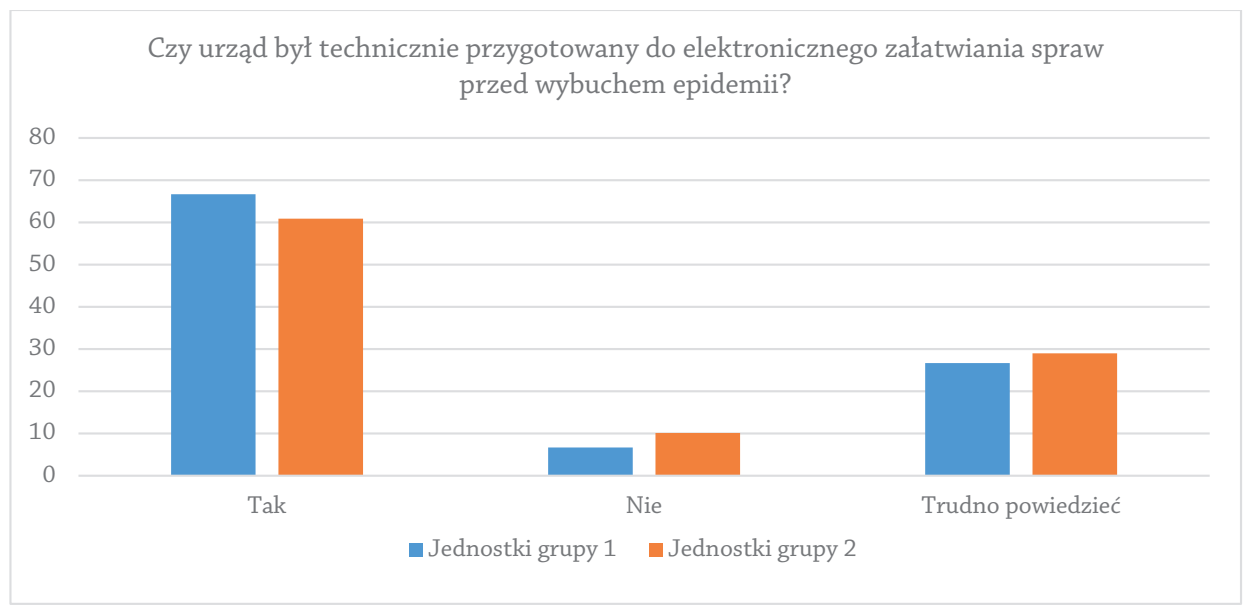

Opracowanie własne na podstawie dokumentacji zebranej w toku projektu.

\section{Przygotowanie merytoryczne}

Personel i jego przygotowanie merytoryczne, doświadczenie oraz umiejętności stanowią czynnik immanentny dla sprawnego funkcjonowania każdej jednostki organizacyjnej. Nader ważne jest także - co szczególnie ujawniła sytuacja kryzysowa spowodowana epidemią COVID-19 - dostosowanie się do nowej sytuacji. W związku z nowymi warunkami pracy urzędników samorządowych, obejmującymi nową jej organizację, szersze wykorzystanie elektronicznych kanałów komunikacji, zarówno z klientami, jak i wewnętrznie, oraz możliwość pracy zdalnej, zasadne stało się pytanie o wcześniejsze przygotowanie merytoryczne pracowników w zakresie wykorzystywania dokumentów elektronicznych i systemów teleinformatycznych. 
Kadra kierownicza urzędów pierwszej i drugiej grupy respondentów w przeważającej większości potwierdziła, iż przed wybuchem epidemii pracownicy zostali przeszkoleni w zakresie wykorzystania dokumentu elektronicznego i systemów teleinformatycznych (wykres 16).

Wykres 16. Przeszkolenie pracowników w zakresie wykorzystania dokumentu elektronicznego i pracy z systemami teleinformatycznym w ocenie szczebla kierowniczego

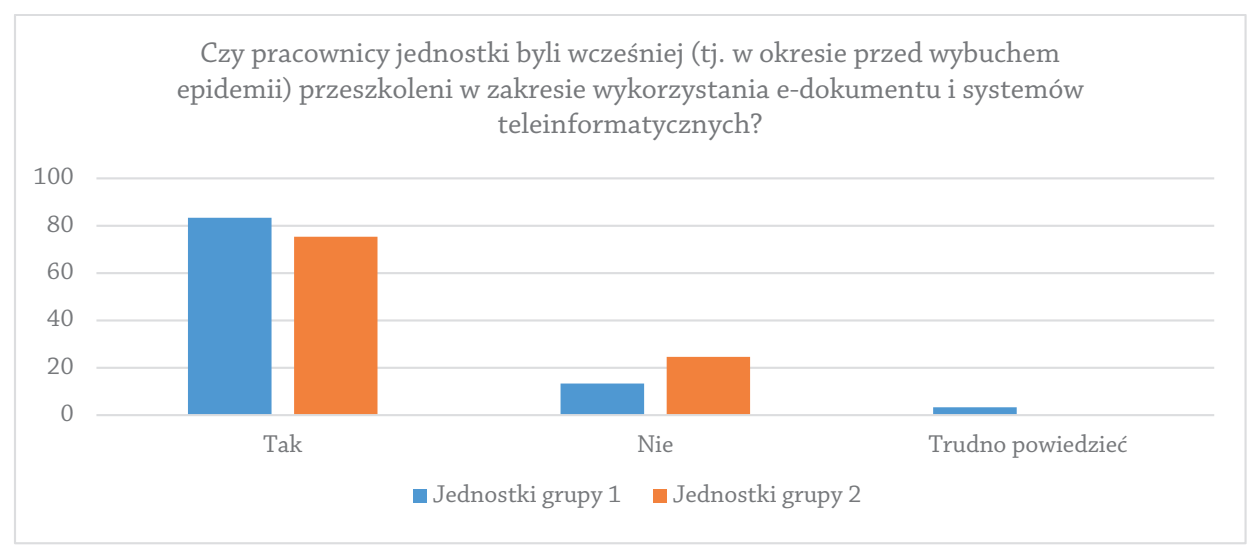

Opracowanie własne na podstawie dokumentacji zebranej w toku projektu.

Wg oceny pracowników szeregowych (wykres 17) przeszkolenie to nie było wystarczające. Niemal 35\% respondentów nie było przed wybuchem pandemii szkolonych w zakresie korzystania z nowoczesnych form kontaktów i sposobów załatwiania spraw. Jeszcze gorzej kwestia ta zarysowała się wśród ankietowanych z drugiej grupy badawczej (które działały w systemie tradycyjnym, ale wykonywanie czynności kancelaryjnych i wewnętrzny obieg pism wspomagały narzędziem informatycznym), gdzie było aż $46 \%$ odpowiedzi przeczących.

Można zauważyć, że grupa pracowników, która przed wybuchem pandemii miała szersze możliwości korzystania z form szkolenia (w większym stopniu zatrudnieni w jednostkach z grupy badawczej 1.), wykorzystanie posiadanej wiedzy w sytuacji kryzysowej oceniła pozytywnie (wykres 18). Urzędnicy, którzy nie byli wcześniej przeszkoleni, mieli większe trudności przy określeniu swojej wiedzy i umiejętności jako wystarczających wobec wyzwań pracy w okresie tzw. lockdownu. 
Wykres 17. Przeszkolenie pracowników w zakresie komunikacji elektronicznej i elektronicznego załatwiania spraw w ocenie pracowników niższych szczebli

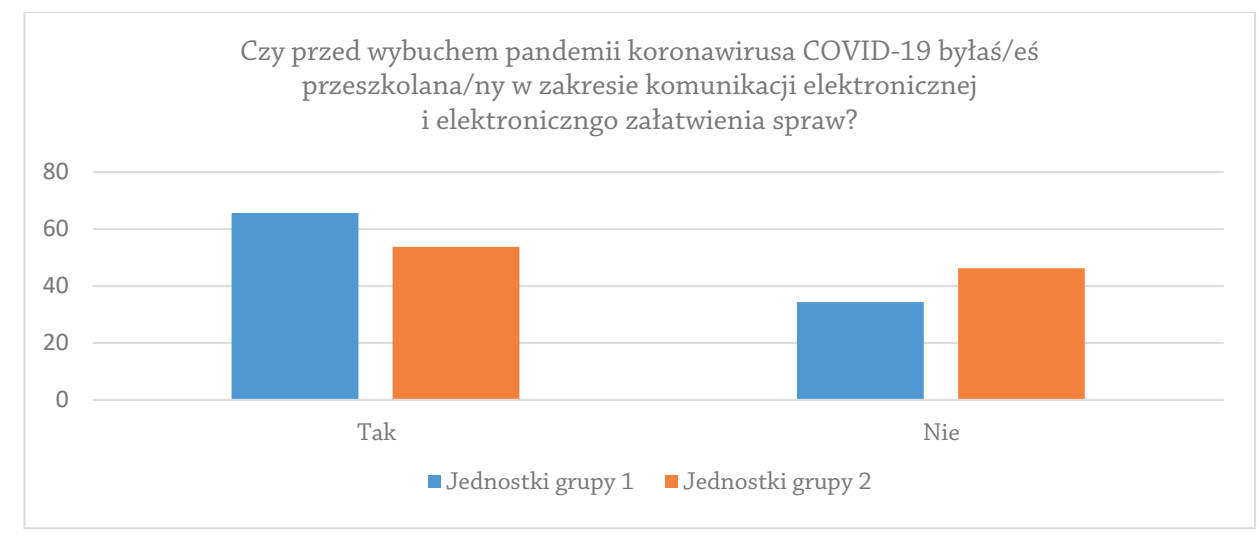

Opracowanie własne na podstawie dokumentacji zebranej w toku projektu.

Wykres 18. Wiedza i umiejętności pracowników w obliczu pandemii koronawirusa SARS-

$-\mathrm{CoV}-2$

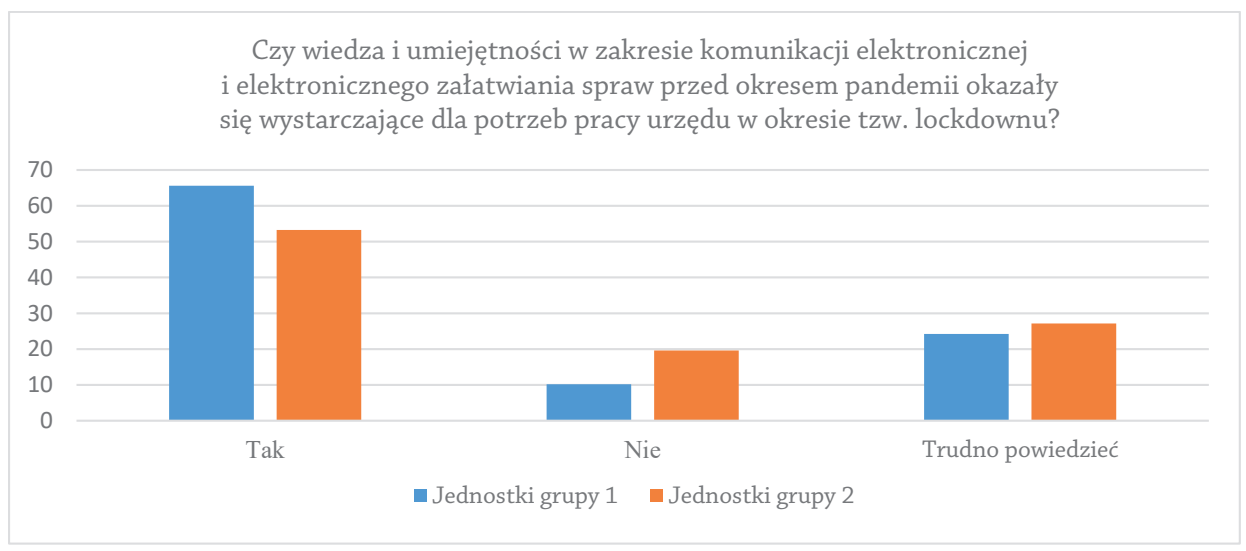

Opracowanie własne na podstawie dokumentacji zebranej w toku projektu.

Na podstawie przedstawionych powyżej przesłanek można wysnuć wniosek, że dla większości pracowników nowa forma pracy, narzędzia wykorzystywane w dobie pandemii oraz odmienne realia były wyzwaniem także w kontekście biurowości. Naturalnym więc staje się postulat o wprowadzenie systematycznych szkoleń pracowników w związku z permanentnym i dynamicznym procesem informatyzacji. Potrzebę tę potwierdzili respondenci (wykres 19), a podnoszenie 
kompetencji od lat uznawane jest wręcz za czynnik warunkujący osiągnięcie sukcesu w procesie wdrażania informatyki w działalności administracji publicznej.

Wykres 19. Potrzeba poszerzenia umiejętności i wiedzy pracowników jednostki w ocenie szczebla kierowniczego

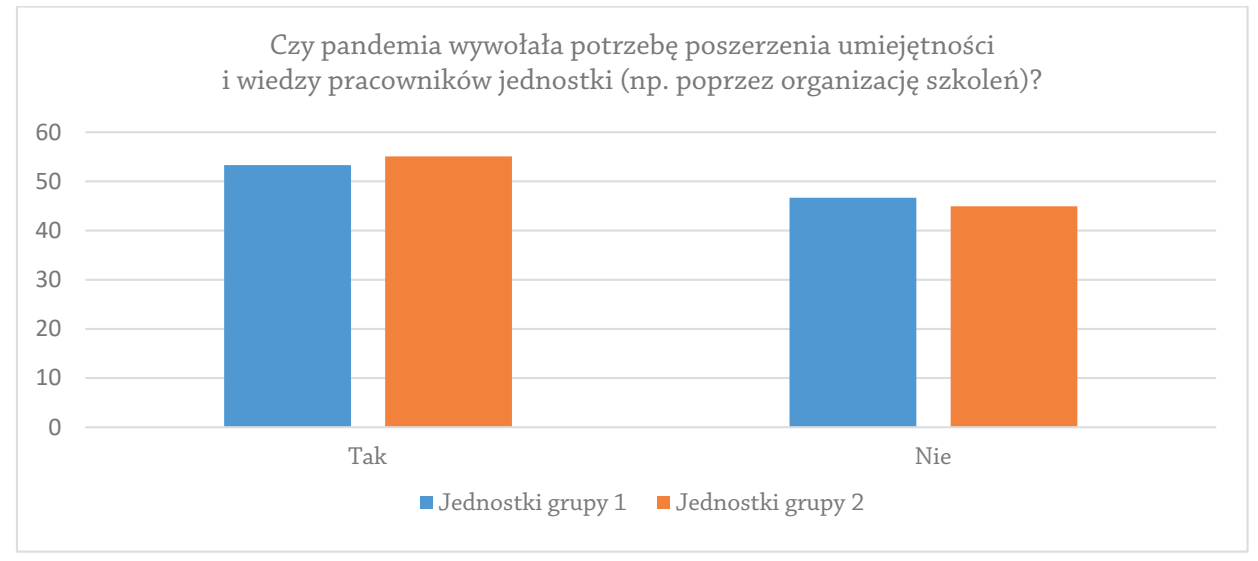

Opracowanie własne na podstawie dokumentacji zebranej w toku projektu.

\section{Podsumowanie}

Pandemia koronawirusa SARS-Cov-2 oraz wywoływanej przez niego choroby COVID-19 niewątpliwie wywarła znaczący wpływ na funkcjonowanie jednostek administracji publicznej, w tym administracji samorządowej. W sposób istotny i zauważalny oddziaływała na szersze wykorzystanie systemów informatycznych w działalności urzędów. Należy podkreślić, że działania z tym związane - tak jak wszystkie inne podejmowane w obliczu epidemii - nie były zaplanowane. Działano doraźnie, w obliczu dynamicznie zmieniającej się sytuacji. Zmieniono tryb pracy urzędów, wprowadzono pracę zdalną, ograniczono bezpośredni, fizyczny kontakt z otoczeniem zewnętrznym. Na podstawie zgromadzonego materiału badawczego oraz analizy wewnętrznych normatywów regulujących pracę zdalną można zauważyć zróżnicowany stopień głębi informacyjnej dotyczącej postępowania $z$ dokumentacją. Wskazuje to na niski poziom kultury dokumentacyjnej, który z pewnością oddziałuje na wiele aspektów zarządzania dokumentacją, w tym kompletność zachowanych materiałów, ich zawartość i uporządkowa- 
nie. Brak powszechnych regulacji, związanych z bezpieczeństwem danych i cyber bezpieczeństwem spowodował, że jedynie nieliczne podmioty unormowały procedurę pobierania dokumentów z siedziby urzędu. Wszystko to wskazuje na spontaniczne, a w konsekwencji nie do końca przemyślane, działania. Kolejnym efektem braku poprawnych praktyk kancelaryjnych jest niedostateczna świadomość o podstawach prawnych regulujących wykonywanie czynności kancelaryjnych, rozproszenie przepisów normujących biurowość oraz błędne stosowanie terminologii ${ }^{46}$. Świadczy to o niedostatecznej wiedzy, nieznajomości przepisów prawa oraz wciąż marginalnym traktowaniu w administracji publicznej kwestii związanych z biurowością. Konieczna jest organizacja stałych szkoleń z zakresu biurowości, elektronicznego załatwiania spraw oraz możliwości wykorzystania systemów elektronicznego zarządzania dokumentacją.

Badania przeprowadzone w ramach grantu „Biurowość w czasach pandemii. Wpływ epidemii COVID-19 na informatyzację biurowości w administracji publicznej" jednoznacznie wskazały na coraz powszechniejsze wykorzystanie dokumentu elektronicznego w komunikacji urzędowej oraz stosowanie narzędzi teleinformatycznych do celów dostępu do usług publicznych i załatwiania spraw Należy przy tym zauważyć, że szersze wykorzystanie e-dokumentu przy załatwianiu spraw w jednostkach, w których wcześniej sporadycznie korzystano z nowoczesnych technologii, doprowadziło do powstawania dokumentacji hybrydowej (jednoczesnego posługiwania się formą tradycyjną i elektroniczną), w związku z sytuacją pandemii. Pandemia spowodowała powielanie czynności oraz większe obciążenie urzędników (m.in. poprzez kopiowanie i przesyłanie wpływającej korespondencji w formie cyfrowej, ale także drukowanie oraz archiwizowanie w formie drukowanej dokumentów wpływających w postaci elektronicznej, przy jednoczesnym zachowaniu e-dokumentu). Niektóre praktyki z pewnością będą stosowane po ustaniu pandemii, konieczna więc będzie ich rewizja, modernizacja oraz ulepszenie.

Okres pandemii uwidocznił potrzebę inwestowania w infrastrukturę umożliwiającą pracę w warunkach nadzwyczajnych w trybie zdalnym oraz z szerszym wykorzystaniem dokumentu elektronicznego. Sprzęt i oprogramowanie zakupio-

46 Wszystkie przebadane podmioty działały w oparciu o jedną instrukcję kancelaryjną, jednak w zakresie dokumentowania przebiegu załatwiania spraw - wskazywano także na normatywy wewnętrzne, regulaminy organizacyjne, zarządzenia kierowników jednostek w sprawie obiegu dokumentacji itd. W toku badania zauważono również, że urzędnicy mieli problem przy określeniu systemu wykonywania czynności kancelaryjnych i sposobu organizowania biurowości. 
ne w związku z pandemią będą wykorzystywane także po ustaniu zagrożenia. Warto przy tym podkreślić, że - mając na uwadze rozwój informatyzacji w sposób skoordynowany i planowy - wszelkie zakupy powinny być poprzedzone analizą ukierunkowaną na zapewnienie interoperacyjności z wykorzystywanymi już rozwiązaniami, m.in. w celu optymalnego wykorzystywania danych już zgromadzonych w wewnętrznych i zewnętrznych systemach informatycznych.

Istotną i trudną do zniwelowania barierą spowalniającą proces informatyzacji jest brak sformułowanej strategii rozwoju teleinformatycznego. Zaniedbania w tym zakresie są wieloletnie. Wg badań wykonanych na zlecenie Ministerstwa Administracji i Cyfryzacji pt. Wpływ cyfryzacji na działanie urzędów administracji publicznej w Polsce w 2014 r., w 2014 r. opracowanie planu działań deklarowało jedynie $8 \%$ jednostek samorządowych ${ }^{47}$. Pomimo upływu czasu stan ten nie uległ poprawie. Żadna z jednostek objętych badaniem nie dysponowała na początku 2021 r. strategią rozwoju teleinformatycznego, a w zdecydowanej większości nie rozważało się wdrożenia systemu elektronicznego zarządzania dokumentacją. Można zatem wnioskować, że czynione działania mają charakter krótkotrwały i spontaniczny

Analizując wpływ pandemii na informatyzację biurowości jednostek samorządowych podczas dwóch fal rozprzestrzeniania się COVID-19, można wnioskować, że był on w większym stopniu widoczny w podmiotach, w których proces wdrażania narzędzi informatycznych postępował wcześniej z mniejszą intensywnością.

Uczestnicy badania ankietowego opowiedzieli się jednoznacznie za pełną informatyzacją biurowości, docenili walory narzędzi informatycznych w procesie zarządzania dokumentacją oraz dostrzegli możliwości automatyzacji wykonywania niektórych czynności kancelaryjnych. Badania wykazały ponadto, że urzędy w okresie trwania epidemii wdrażały systemy wspomagające biurowość. Trzeba mieć jednak na uwadze, że były to jedynie narzędzia wspomagające, a nie pełne implementacje systemu EZD. W efekcie spotęgowano więc stan różnorodności stosowanych rozwiązań, a takie działania należy uznać za doraźne i czynione pod wpływem bieżących potrzeb.

47 Zob.: Wpływ cyfryzacji na działanie urzędów administracji publicznej w Polsce w 2014 r. - badanie wykonano na zlecenie Ministerstwa Administracji i Cyfryzacji, grudzień 2014 r., s. 10, 23-24, https://dane.gov.pl/pl/dataset/699,wpyw-cyfryzacji-na-dziaanie-urzedow-administracji-publicznej-w-polsce [dostęp: 20.03.2021]; E. Kuzionko-Ochrymiuk, Informatyzacja administracji publicznej w województwach Polski, „Optimum. Econimic Studies” 2018, nr 1 (91), s. 166. 
Jednostki objęte badaniem w zdecydowanej większości nie planowały wdrożenia systemu EZD na przestrzeni najbliższych lat, co nie koresponduje z potrzebami akcentowanymi przez ich pracowników. Ignorowanie oddolnych postulatów należy odebrać negatywnie.

Informatyzacja biurowości w jednostkach samorządu terytorialnego prowadzona jest od lat w toku i przy okazji wielkich projektów, ale także małych, lokalnych inicjatyw. Mimo niewątpliwych sukcesów, zasadne jest stwierdzenie, że przed decydentami i pracownikami urzędów stoi wiele wyzwań: unifikacja działań w skali krajowej, uruchomienie oraz wdrożenie systemu EZD RP, zwiększenie liczby podmiotów organizujących kancelarię w oparciu o system elektronicznego zarządzania dokumentacją, zachęcenie obywateli do kontaktów z urzędami drogą elektroniczną. Epidemia koronawirusa SARS-CoV-2 oraz wszystkie jej konsekwencje nie tylko uwidoczniły znaczenie informatyzacji biurowości, ale także - co można stwierdzić bez żadnych wątpliwości - wpłynęły na jej rozwój.

\section{Źródła}

Dane badawcze zgromadzone w toku realizacji projektu przechowywane w siedzibie Wydziału Nauk Historycznych Uniwersytetu Mikołaja Kopernika w Toruniu, ul. Wł. Bojarskiego 1, 87-100 Toruń.

Rozporządzenie Rady Ministrów z dnia 10 kwietnia 2020 r. w sprawie ustanowienia określonych ograniczeń, nakazów i zakazów w związku z wystąpieniem stanu epidemii (Dz. U. 2020, poz. 658 ze zm.)

Rozporządzenie Ministra Zdrowia z dnia 13 marca 2020 r. w sprawie ogłoszenia na obszarze Rzeczypospolitej Polskiej stanu zagrożenia epidemicznego (Dz. U. 2020, poz. 433).

Rozporządzenie Ministra Zdrowia z dnia 20 marca 2020 r. w sprawie ogłoszenia na obszarze Rzeczypospolitej Polskiej stanu epidemii (Dz. U. 2020, poz. 491).

Ustawa z dnia 2 marca 2020 r. o szczególnych rozwiązaniach związanych z zapobieganiem, przeciwdziałaniem i zwalczaniem COVID-19, innych chorób zakaźnych oraz wywołanych nimi sytuacji kryzysowych (Dz. U. 2020, poz. 1842).

Statystyki usług: ePUAP - Pismo ogólne do podmiotu publicznego - stary wzór, https://widok.gov. pl/services/ePUAP-Pismo-ogolne-do-podmiotu-publicznego-stary-wzor/ [dostęp: 31.03.2021]. Wyniki badania ankietowego „Wpływ epidemii COVID-19 na informatyzację biurowości w administracji publicznej”, https://dobrepraktyki.umk.pl/pages/dane_badawcze/ [dostęp: 11.06.2021]. 


\section{Bibliografia}

Degen R., Zarzq̨dzenie dokumentacją w polskich badaniach, [w:] Zarzq̨dzanie dokumentacja. Badanie i praktyka, Biblioteka Zarządcy Dokumentacji, t. 7, red. R. Degen, M. Jabłońska, Toruń 2016., s. 37-58.

Kubicka-Żach K., Praca zdalna w administracji przedłużona do 17 stycznia, https://www.prawo.pl/samorzad/praca-zdalna-w-administracji-zostala-przedluzona,504789.html [dostęp: 17.03.2021].

Kuzionko-Ochrymiuk E., Informatyzacja administracji publicznej w województwach Polski, „Optimum. Econimic Studies" 2018, nr 1 (91), s. 159-175.

Ochrona danych osobowych podczas pracy zdalnej, https://uodo.gov.pl/pl/file/2786 [dostęp: 26.03.2021].

Pierwszy przypadek koronawirusa w Polsce, https://www.gov.pl/web/zdrowie/pierwszy-przypadek-koronawirusa-w-polsce [dostęp: 9.04.2021].

Robótka H., Wspótczesna biurowość. Zagadnienia ogólne, Biblioteka Zarządcy Dokumentacji, t. 1, Toruń 2010.

Robótka H., Zarzq̨dzanie dokumentacja w dobie informatyzacji, [w:] Zarzq̨dzanie dokumentacja $w$ instytucji. Czynniki sprzyjające i ograniczenia, Biblioteka Zarządcy Dokumentacji, t. 9, red. R. Degen, M. Jabłońska, Torun 2020, s. 97-116.

Rzq̨d zapowiada zaszczepienie wszystkich 60-latków do końca miesiąca, https://www.onet.pl/informacje/onetwiadomosci/rzad-zapowiada-zaszczepienie-wszystkich-60-latkow-do-konca-miesiaca/17s2psx,79cfc278 [dostęp: 2.04.2021].

Serwis Rzeczypospolitej Polskiej. EZD RP w administracji publicznej, https://www.gov.pl/web/cyfryzacja/ezd-rp-w-administracji-publicznej [dostęp: 9.04.2021].

Smoczyński M., Wspótczesny zarządca dokumentacji a zarzq̨dzający aktami specjalista-organizator wg koncepcji Jana Kościołka, „Archiwa - Kancelarie - Zbiory” 2017, nr 8 (10), s. 111-128.

M. Smoczyński, Biurowość w czasach pandemii. Wpływ epidemii Covid-19 na informatyzację biurowości w jednostkach administracji samorzadowych i rzqdowych w terenie, „Archeion” 2021, t. 122, DOI: 10.4467/26581264ARC.21.009.14489.

Szymańska E., Efektywność przedsiębiorstw - definiowanie i pomiar, „Roczniki Nauk Rolniczych” 2010, t. 97, s. 152-164.

Wdrażanie wybranych wymagań dotyczących systemów teleinformatycznych, wymiany informacji w postaci elektronicznej oraz Krajowych Ram Interoperacyjności na przykładzie niektórych urzędów gmin miejskich i miast na prawach powiatu, https://www.nik.gov.pl/kontrole/P/14/004/ [dostęp: 12.04.2021].

Wpływ cyfryzacji na działanie urzędów administracji publicznej w Polsce w 2014 r. badanie na zlecenie Ministerstwa Administracji i Cyfryzacji, grudzień 2014 https://dane.gov.pl/pl/dataset/699,wpyw-cyfryzacji-na-dziaanie-urzedow-administracji-publicznej-w-polsce [dostęp: 20.03.2021]. 